\title{
SAFEGUARDS FOR THE RIGHTS OF PATIENT AND DOCTOR UNDER A NATIONAL HEALTH PROGRAM-THE BRITISH NATIONAL HEALTH SERVICE ACT OF 1946
}

ON November 7, 1946, the British Parliament enacted Britain's first comprehensive health legislation-the National Health Service Act. ${ }^{1}$ Recognition that established public and private institutions had not extended adequate health care to everyone prompted passage of the Act. ${ }^{2}$ Complete divorcement of the right to care from ability to pay was considered the only way to accomplish this. To accord with this principle the National Health Service is financed primarily from general tax funds-it is not an insurance program. ${ }^{3}$ Thus the

1. $9 \& 10 \mathrm{Gro}, 6,1946$, c. 81 (hereinafter cited as NHSA), as amended in part by National Health Service (Amendment) Act, 1949, 12, 13 \& 14 GEo. 6, c. 93 (hereinafter cited as NHS (Amendment) A, 1949). "It shall be the duty of the Minister of Health ... to promote the establishment... of a comprehensive health service designed to secure improvement in the physical and mental health of the people ... and the prevention, diagnosis and treatment of illness, and for that purpose to provide or secure the effective provision of services ...." NHSA §1(1). The Act was supported and passed by the Labour and Liberal Parties. 428 H. C. Deb. 1399 (5th ser. 1946). While the Conservative Party was pledged to a comprehensive health service, it opposed the Bill. See, e.g., Speech of Willink, former Conservative Minister of Health, $422 \mathrm{H}$. C. DEB. 224,225 (5th ser. 1946).

The Act applies only to England and Wales. Similar legislation for Scotland, National Health Service (Scotland) Act, 1947, 10 \& 11 GEo. 6, c. 27, as amended in part by NHS (Amendment) A, 1949, contains separate administrative provisions required because of differences in geography and local governmental structure. This comment does not distinguish between the two Acts, and citations generally refer only to National Health Service Act, 1946.

2. See, e.g., Report on the British Healte Services (Political and Economic Planning, 1937), prepared by an independent non-party group. The British Medical Association, the counterpart of the American Medical Association, was one of the severest critics of the nation's inadequate health services. See, Medical Planning Coanission, Draft Interim Report 5-11 (1942), reprinted in part in Morgan, Pantper Medical Care, Health Insurance, or National Health Service: The British Experiment, 21 THe SoctaL. SERVICE REv. 446, 450 (1947). For a summary of numerous government and other reports reaching the same conclusion see, A National Health Service (Card. No. 6502) 53-77 (1944).

3. See, e.g., speech of Bevan, Minister of Health, 422 H. C. DEв. 43 (5th ser. 1946). The World War II coalition government of Conservative, Labour and Liberal Party members, in its White Paper proposing a comprehensive health service, declared that health care must be separated from personal means. A National HeALTH SERVice (CMD. No. 6502) 47 (1944). As early as 1926, the Majority Report of tHe Royad CoMrMission on Natronal Healti Insurance objected to any broadening of National Health Insurance coverage as a method of extending medical services: "The ultimate solution will be . . . in the direction of divorcing the medical services entirely from the insurance system and reorganizing it . . . as a service to be supported from the general public funds." Report on the Britise Health Services (Political and Economic Planning) 212 (1937). Though financed primarily from general tax funds, only about $10 \%$ of total 
Act makes the government responsible for providing free medical, dental, hospital, pharmaceutical and allied services for all who want them. ${ }^{4}$

Regimentation of individuals using and providing service might facilitate achievement of the Act's objectives. But respect for the dignity of the human being is a basic concept underlying the statute: it rests on the theory that comprehensive free health care, like free education. is essential to individual freedom and to the welfare of a democratic society. And Parliament, anxious

cost is paid out of contributions made under the National Insurance Act, 1946, 9 \& 10 Geo. 6, c. 67. See, The Admimistration of the National Health Services (Seventh Report from the Select Committee on Estimates, 1948-49, HCR 176, 178) (II 10, 11 (1949), (hereinafter cited as Select Commitree Report on Administration of NHS, 1949).

None of the numerous American bills for providing medical care go this far. Each perpetuates the troublesome eligibility problem. Insurance qualifications or a humiliating 'means test' which involves investigations of an individual's financial resources are retained: See e.g., the most comprehensive of all proposals, the Administration Bill S.1679 which requires insurance status for eligibility $(\$ 704)$ with special provision for the needy ( $\$ 705)$. Both the Hill Bill S.1456 (\$712a) and the Flanders-Ives Bill S.1970 ( $\$ 723 \mathrm{n})$ would use a means test to determine eligibility for even subsidized voluntary insurance. See Anderson, Compulsory Medical Care Insurance, 1910-1950, 273 ANnals 106, 111 (1951); Comment, The Essentials of An Adequate Health Program, 59 Y ALE L.J. 292, 301-3 (1950). For the American Medical Association's questionable view that most Americans deprive themselves of adequate medical care by choice rather than necessity, see statement of Dr. Bauer that American consumers have decided that they can afford $1 \mathrm{I} / 2$ times as much for alcoholic beverage as for medical care, in Hearings before a Stbcommittee of the Committee on Labor and Publice Welfare on $S .1106, S .1456$, S. 1581, and S. 1679, 81st Cong., 1st Sess. 209 (1949).

4. NHSA $\S 1$ (1). The range of health care offered includes general practitioner and specialist services as well as those of dentist, optician, midwife, and nurse. Mental health care, in-patient and out-patient hospital care, blood transfusions, prescribed drugs, appliances such as hearing aids, artificial limbs, wigs, and bandages are also supplied. No limit is placed on the cost or the length of care. $I d$. $\S \S 2,3,16-18,21-9,33,38-41$. However, "extras" not prescribed by the doctor, such as spectacles of a more expensive variety than recommended and repairs of service-supplied appliances due to a patient's negligence may result in extra charges. Id. $\S 44(1)$ (a). Though he has never exercised this power, the Minister may now impose a nominal charge for prescriptions and recover costs of service rendered to persons "not ordinarily resident in Great Britain." NHS (Amendment) A, 1949, §§ 16, 17; note 58 infra.

Because of high defense costs, the 1951 Budget proposes to charge half-price for adults' dentures and spectacles. Speech of Gaitskell, Chancellor of the Exchequer, 488 H.C. DEB. 851-2 (5th ser. 1951).

5. For the general proposition that a democratic society is responsible for the health and education of the individual for his own and the common good, see Justice Brandeis, True Americanism in Anshen, Freedom Its Meaning 349-55 (1940). Some modern social philosophers emphasize that freedom is meaningless unless government provides opportunities for every individual to realize his potentialities. See EDMan, FountainHEAdS OF FreEdoM 186-8 (1941) and BaRKER, REFLECTIONS ON GOVERNMENT 190-4 (1942). Sir William Beveridge emphasized "five giants" which block the way to individual development: "Want, Disease, Ignorance, Squalor and Idleness." SocraI Insurance and Allied Services (CMr. No. 6404) 6 (1942) (hereinafter cited as BEVERIDGE REPORT). "We now realise that the wealth of a nation depends upon the health 
to avert the danger of regimentation, drafted the Act to ensure freedom of choice for patient and doctor, as well as the doctor's professional independence. $^{6}$

\section{Background and Policy}

Wide gaps and deficiencies in health resources characterized a complicated patchwork of public and voluntary charitable and insurance institutions which had evolved haphazardly over more than a century in Britain. ${ }^{7}$ Poor Laws provided for limited general-practitioner and hospital services to the "destitute sick" who could meet a stringent test of poverty. ${ }^{8}$ Two distinct hospital systems, one dependent on charity, the other on local public funds, resulted in wasteful overlapping in some areas. Others were left with grossly inadequate facilities. ${ }^{\circ}$ Voluntary hospital insurance schemes, roughly analagous to Blue

of the individual, but we also understand that we have a responsibility towards anyone suffering from ill-health and that we have to share with him the benefit of our production until such time as he can be restored to health." Speech of Davies, 422 H. C. DEB. 247 (5th ser. 1946). See also Report on The British Health Services (Political and Economic Planning) 211 (1937).

6. "There is a certain danger in making personal health the subject of a national service at all. It is the danger of over-organisation, of letting the machine designed to ensure a better service itself stifle the chances of getting one.... [B] ut organisation must be seen as the means, and never for one moment as the end." A Natronal Healtr SERVICE (CMd. No. 6502) 8 (1944). And see, e.g., speech of Bevan, Minister of Health, 447 H. C. DEB. 35,40 (5th ser. 1948).

7. See, e.g., A National Health Service (Card. No. 6502) 6-8, 53 (1944). Though the patchwork contained some very good pieces, disorganization and maldistribution of available personnel and facilities were major defects. Hill, Has Britain Shoun That Health Insurance Can Work? 23 The Social SeRvice Rev. 435, 436 (1949). See also speech of Bevan, Minister of Health, 422 H. C. DEB. 43 (5th ser. 1946).

Voluntary insurance programs, public and private charities, government assistance for special groups, and the sliding price scale of many physicians have failed to extend to all Americans the benefits that modern science provides. See testimony of J. Donald Kingsley, Acting Federal Security Administrator, in Hearings before a Subcommittee of the Committee on Labor and Public Welfare on S. 1106, S. 1456, S. 1581, and S. 1679, 81st Cong., 1st Sess. 79-109 (1949). For an outline of the present role of federal, state, or local government in providing medical care see Roberts, Public Medical Care: The Overall Picture, 273 ANovals 69 (1951). For a discussion of the limited scope and coverage of voluntary insurance schemes providing hospital and surgical care, see Klem, Voluntary Medical Insurance, 273 AnNats 99 (1951). For general discussion of American medical services, see 273 Ansals (1951), and Comment, The Esscutials of an Adequate Health Program, 59 Y ALE L.J. 292-308 (1950).

8. See Morgan, supra note 2 at 447; and A National Health Service (CND. No. 6502) 53 (1944). See also note 3 supra.

9. A Nationai Health Service (Caid. No. 6502) 54-9 (1944). There was no hospital "system." The best hospital facilities often were available where least needed. But even in areas where hospitals were heavily concentrated, shortages of beds and staff were frequent. Many hospitals were too small to provide general treatment. Seventy per cent had less than 100 beds. See speech of Bevan, 422 H. C. DEB. 44,49 (5th ser. 1946). "[T] he hospital situation had cried out for reform because of the depletion of 
Cross, gave limited coverage to a quarter of the population. ${ }^{10}$ The National Health Insurance Act of 1911, Britain's first major medical-care legislation, covered only the employed half of the population, not their families and dependents. ${ }^{11}$ Benefits extended primarily to the services of the general practitioner and not to dental, optical, and hospital care. ${ }^{12}$

The 1942 Beveridge Report on Social Insurance, recognizing the shortcomings in Britain's health services, declared that no social security program could be successful without comprehensive health care for all members of the community. ${ }^{13}$ In Britain, social security provides income to replace, in part at least, earnings interrupted by unemployment, whether caused by economic conditions, illness, accident, or age. Health care would shorten or prevent many such interruptions of these earnings. ${ }^{14}$ The wartime Coalition Government accepted this reasoning and in 1944 published a White Paper recommending a national health service. ${ }^{15}$ Such a program meant that the piecemeal measures of old would no longer suffice; reorganization of all existing services on a new basis became necessary. ${ }^{16}$ Thus, with the passage of the Act in 1946, came the repeal of more than two dozen pieces of legislation which marked the long historical evolution to the National Health Service. ${ }^{17}$

charitable funds (actual and potential) and the financial difficulties of local authorities." Communication to the Yale Law Journal from O. Kahn-Freund, Professor, London School of Economics and Political Science, University of London, August 28, 1951. See also Brady, Crisis in Britain 375-81 (1950) and Health Services in Britain (British Information Services, I. D. No. 753 rev.) 4 (1948).

10. BEVERTDE REPORT 160. At the end of 1949, 66 million persons, or about $44 \%$ of the total population of the United States, had insurance providing a varying degree of coverage for hospital expense. See Klem, supra note 7, at 99.

11. Eligibility depended on insurance status and insurance was available only to the employed, not the self-employed, earning less than 420 pounds a year. Speech of Bevan, 422 H. C. Deb. 43 (5th ser. 1946) and A National Healtr Service (Card. No. 6502) 54 (1944). Aside from limited scope and coverage, the National Health Insurance Scheme had two fundamental weaknesses. First, the whole machinery of administration was too costly, for the actuarial complexities of the Scheme consumed much of the time of local and civil service committees. Secondly, like in any insurance scheme, premium collections, not health needs, delimited services rendered. See Morgan, supra note 2, at 449; BEVERIDGE REPORT 28-30.

12. Though hospital and specialist services were not made available under the scheme, some dental and optical treatment could be obtained on partial payment by about half the insured population. A National Health Service (CMd. No. 6502) 53, 64-5 (1944). For a comprehensive discussion of the National Health Insurance Scheme see HarRIs, National Health Insurance 1911-1946 (1946) and Report on the British Health SERvices (Political and Economic Planning) 194-229 (1937).

13. Beveridge Report 15, 48, 158-63.

14. "It is a logical corollary to the payment of high benefits in disability that determined efforts should be made by the State to reduce the number of cases for which benefit is needed. . . . Disease and accidents must be paid for in any case, in lessened power of production and in idleness. ..." Id. at 158.

15. A National Health Service (Cimd. No. 6502) 5, 76 (1944).

16. Id. at $11,47$.

17. NHSA, Eighth-Tenth Schedules. 
The Act, which, with Britain's new Social Security Laws, went into operation on July 5, 1948, ${ }^{18}$ sought to give effect to two interrelated objectives: (1) To afford everyone, irrespective of income, an equal opportunity to benefit from the best medical services available; (2) To develop and coordinate the nation's health resources so as to provide a comprehensive service covering every preventative as well as curative branch of medical and auxiliary activities. ${ }^{19}$

To achieve these objectives, the Act divided the Nation's health resources into three groups under the auspices of the Minister of Health. ${ }^{20}$ Specialist

18. The National Health Service Act is only one of five major pieces of legislation which are portions of a single overall social security program insuring against incapacity, disablement, unemployment, old age, and other economic risks. The Family Allowances Act, 1945, which had begun operations in 1946, provides weekly cash allowances to a mother for each child under school-leaving age, except the first. Allowances are available to all and are subject to income tax. $8 \& 9$ Geo. 6, c. 41 . The National Insurance (Industrial Injuries) Act, 1946, and the National Insurance Act, 1946, cover the whole population for most economic hazards from womb to tomb. The scheme is on a strictly actuarial basis, is contributory and compulsory. $9 \& 10$ GEo. 6, cc. 62, 67. The National Assistance Act, 1948, is a residual service for those who fall outside the scope of the Insurance Acts either because of the nature of their need or because they have not made enough contributions to qualify for benefits. $10 \& 11$ GEo. 6, c. 29 . For an analysis of this legislation see Brady, Crisys in Britain 307-401 (1950), Social Services IN BritaIn (British Information Services, I.D. No. 780 rev.) 3-11 (1948), and Moss, The British National Health, Welfare, and Insurance Services, 35 Iowa L. Rev. 237 (1950).

19. NHSA $\$ 1$. These objectives and the concept of governmental responsibility to attain them had the support of the major political parties and the principal professional organizations, including the British Medical Association. See the Coalition Government's A National Health Service (CMrd. No. 6502) 8-12, 47 (1944); Medrcal Planning CoMmisston, Drafr Interim Report 8 (1942), reprinted in part in Morgan, supra note 2, at 452; speech of Law for the Conservative Party, 422 H. C. DEв. 66-7 (5th ser. 1946). See, generally, 422 H. C. DEB. 43 et seq. (5th ser. 1946).

Though many Americans support similar objectives, some fear their achievement by any program involving tax support and government administration. See Anderson, Comprlsory Medical Care Insurance, 1910-1950, 273 Annals 106, 112 (1951) ; Ewing, The Nation's Health: A Ten Year Program; A Report to the President 15-22 (1948) ; statement by Dr. Bauer outlining the program of the American Medical Association for the advancement of medicine and public health in Hearings beforc a Subcommittee of the Committee on Labor and Public Welfare on S. 1106, S. 1456, S. 1581, and S. 1679, 81st Cong., 1st Sess. 201-206 (1949) ; address by Dr. Cline, the president of the American Medical Association, Medicine's Case Against Socialization (National Education Campaign American Medical Association) 5-10 (Jan. 1951).

20. NHSA pts. I-IV. For historical reasons the three main branches of the service are administered by three independent though interrelated authorities. Though liaison is not yet perfect among the three groups, it is expected that patients will be able to shift smoothly from one branch of the service to another. See address of Sir John A. Charles, Chief Medical Officer of the Ministry of Health, in Record of Proceedings at the Third Anmual Meeting of Executive Conncils' Association (England) National Health Service 87, 89 (1950) (hereinafter cited as RECoRd ThIRd Executrve Councrls' Assoc. MeEtING); speech of Dr. Hill 490 H. C. Deв. 147 (5th ser. 1951). 
services and all hospitals, except teaching and religious hospitals which the Minister disclaimed, ${ }^{21}$ were placed under the supervision of a system of Regional Boards. ${ }^{22}$ General-practitioner, dental, pharmaceutical and optical services became the responsibility of specially created Local Executive Councils. ${ }^{23}$ And important supplementary services, including the provision of health centres, maternity care, domestic help for the sick and infirm, vaccination and ambulance service, were made functions of local county or borough government.. ${ }^{24}$ (See diagram opposite).

21. See notes 75 to 85 infra and text. Only the hospitals are nationalized. Drugstores and manufacturers and distributors of medical supplies remain under private enterprise. NHSA $\S 6$. Ownership of 2,835 out of the 3,040 voluntary and municipal hospitals in England and Wales with a total of 388,000 staffed beds was vested in the Minister. Under $\$ 6(3)$ of the Act the Minister decided not to take over most of the private, i.e. nursing homes, and religious, hospitals. The services of these hospitals, however, are not denied to patients who wish to use the National Health Service. Arrangements may be made on a contractual basis. Report of the MrNistry of Health 1949 (CArd. No. 7910) 243-4 (1950). Provision is made for preserving the denominational character of religious hospitals transferred to the Minister. NHSA § 61. The transfer of hospital ownership to the Minister was accompanied by existing endowments freed from any trust. All endowments with the exception of those for teaching hospitals were placed in a Hospital Endownments Fund. The income is allocated equitably among Regional Boards for use at their discretion. Capital may be made available on approval by the Minister. Id. §7(4), (5). Conservatives opposed these provisions as violating the wishes of testators. See, e.g., Speech of Strauss, 425 H. C. DEB. 1797 (5th ser. 1946). As a result, if "reasonably possible," objects of existing endowments, particularly for preserving the memory of a person, and any endownments made after the Act came into operation will be honored. NHSA §7(4) (a), (7). And see 428 H. C. DEB. 1074 (5th ser. 1946).

22. NHSA § 11. Britain has been divided into 19 hospital regions, each of which is centered on a medical university. Id. $\$ 11(1)$; and SELECT CoMmitTeE REPORT ON ADMIINISTRATION of NHS 1949, $\Uparrow 46$. Regional Boards, as agents of the Minister, are responsible for planning and administering the hospital and specialist services. Day-today management is in the hands of Hospital Management Committees responsible to the Boards. Teaching hospitals in England and Wales are under the control of a Board of Governors which has the same status as a Regional Board. NHSA $\S 11(5),(8), 12$. All three bodies are legal entities. Id. $\$ 13(1)$.

Repeated recommendations by professional and lay organizations led to the reorganization of the hospitals on a regional basis in order to pool resources on a broad financial base. See, e.g., Report on the British Health Services (Political and Economic Planning) 262-5 (1937) and Medical Planning Cominission, Draft Interim Report (1942), reprinted in part in Hill, Inherent Problems in Planning a Nationai Health Sekvice, 21 The Social Service Rev. 456, 458 (1947). Conservatives, however, sought to keep control in local authorities. See, e.g., Speech of Willink, 422 H. C. DEB. 229-33 (5th ser. 1946).

23. NHSA $\$ \S 31,33,38,40,41$, and Fifth Schedule as amended by NHS (Amendment) A, $1949 \$ 29$. See speech of Bevan, 422 H. C. Deb. 52 (5th ser. 1946), and note 89 infra.

24. NHSA $\$ \$ 19-29$. The administration of services provided by local health authorities will not be discussed in this comment. For discussion of these services see Brady, CrIsIS IN BRITAIN 390-395 (1950). One of the criticisms of the administrative structure is that all health services were not integrated into a complete unit. On the other hand there was general agreement that health services should be as local as possible particularly 


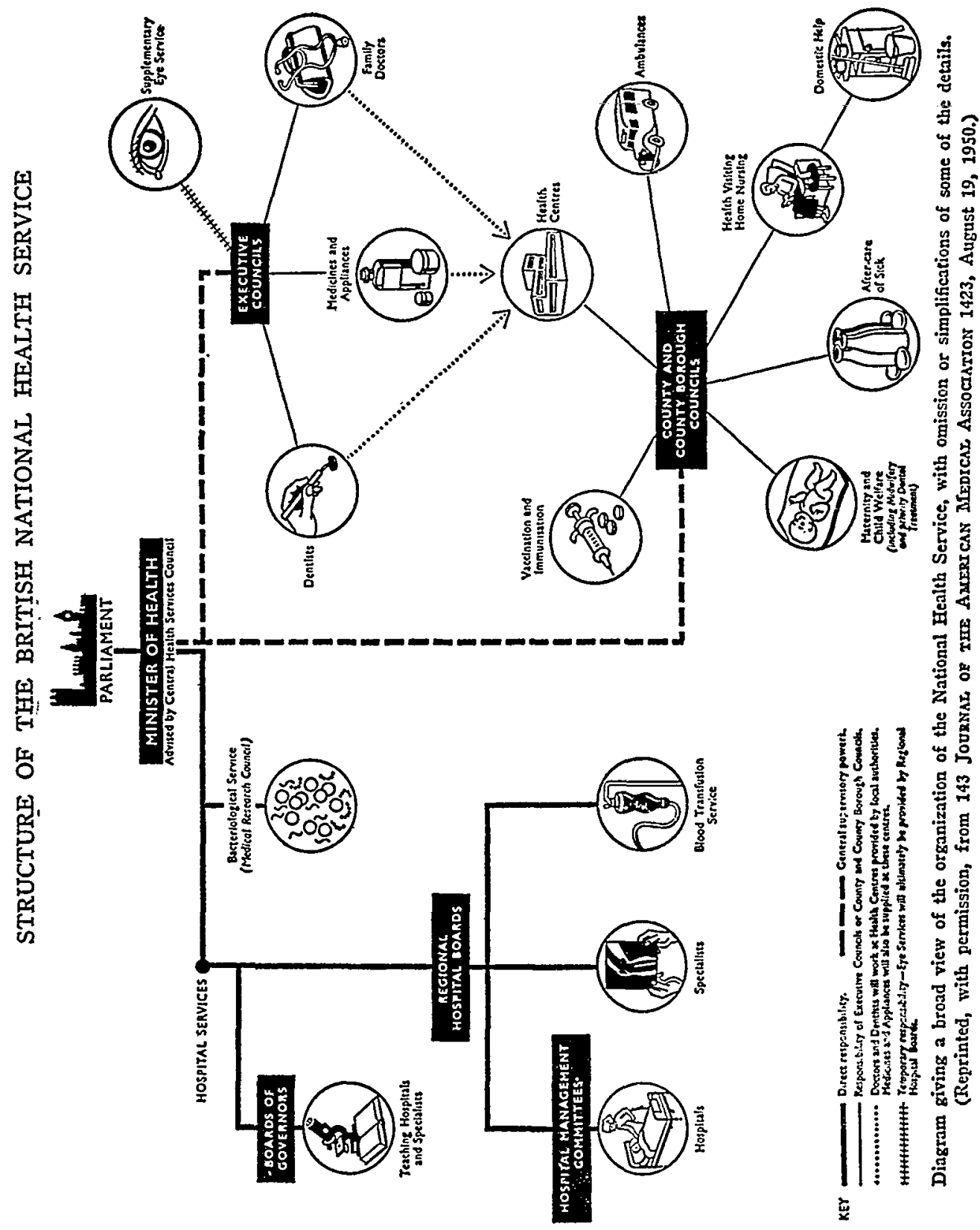


The British government recognized that in administering such an Act in a tree society personal freedom must not be jeopardized. ${ }^{25}$ A national health service, like other group action, might restrict the independence of the individual. ${ }^{26}$ However, supporters of a comprehensive service, including the British Medical Association, believed that regimentation of doctor and patient was not inevitable, and that adequate safeguards could be devised to protect the rights of individuals. ${ }^{27}$ Though opinions differed on what these safeguards should be, there was general agreement on what rights ought to be protected: ${ }^{23}$

for maternity and child welfare. Provision is also made for county and county boroughs to have subcommittees on which local authorities in the area are represented. See speech of Bevan, 425 H. C. DEB. 1739 et seq. and NHSA Fourth Schedule. The proposal to create health centres under local auspices was a large factor in securing the support of the general practitioners. Health centres, of which only a few have been built because of a shortage of building supplies, were visualized as providing office, nursing, clerical and laboratory services for a number of local doctors. A National Heaitr Service (Card. No. 6502) 30, 31 (1944); Rappleye, The National Heaitr Service of Great Britain (Josiah Macy Jr. Foundation pamphlet) 11 (1949).

25. See, e.g., speech of Bevan, 422 H. C. DEB. 43 et seq. (5th ser. 1946) and speech of Key, id. at 206, 213 et seq. See also motion and speech by Bevan, $447 \mathrm{H}$. C. DeB. 35 ct seq. (5th ser. 1948). The motion, which was carried, read in part: "[This House] is satisfied that the conditions under which all the professions concerned are invited to participate are generous and fully in accord with their traditional freedom and dignity." Id. at 35 .

26. See Rogers, Planning for a Broad Health Program, 273 Annals 176 (1951).

"If now, . . . we try to formulate our dominant impression, it is a sense of the vastness and complexity of democracy itself. Modern civilized states are driven to this complication by the dense massing of their populations, and the course of industrial development. The very desire to secure mobility in the crowd compels the adoption of one regulation after another, which limit the right of every man to use the air, the water, the land, and even the artificially produced instruments of production, in the way that he may think best. . . . But the very fact that, in modern society, the individual thus necessarily loses control over his own life, makes him desire to regain collectively what has become individually impossible. Hence the irresistible tendency to popular government . . " Sidney \& Beatrice Webb, Industrial Democracy 849-50 (1920 ed., 1926).

27. See, A National Health Service (CMm. No. 6502) 8 (1944). And see, Hill, The Inherent Problems in Planining a National Health Service, 21 THe Soctal SERvice REv. 456-8 (1947); Means, England's Public Medicine: The Facts, 185 Atr. Montmly 53 (Miarch 1950).

28. See, e.g., debate on methods of pay, abolition of an established doctor's right to sell the goodwill of his practice, the reduction of local borough power with consequent increase in central power, particularly over hospitals, and a doctor's right of appeal from a Tribunal decision, in 425 H. C. DEB. 1689 et seq. (5th ser. 1946) ; 426 H. C. Deb. 392444 (5th ser. 1946); 428 H. C. Deв. 1067 et seq. (5th ser. 1946); and 447 H. C. Deb. 35 ct scq. (5th ser. 1948).

As far as the British Medical Association was concerned, the big question was whether or not the Government, as the Labour Party had often advocated, intended to pay doctors on a full-time salaried basis. Believing that this was so, and that such a method of remuneration would make doctors civil servants, the B.M.A. conducted a campaign against the Bill, threatening to undermine the new service unless the Association could be satisfied on this point. See Brady, CrISIs IN Britain 383 (19.50). The Minister 
(1) Freedom of doctor and patient to use or not to use the public service, and to have private medical care arrangements whether or not doctor, patient or both have joined the service; (2) Freedom of patient to choose and to change his doctor and of doctor to refuse patients; (3) Freedom of doctor to pursue his own professional methods without interference. ${ }^{29}$

\section{Rights of the Patient and the National Health Service}

\section{Freedom of Choice}

While everyone in Britain is automatically eligible for free health care, he may also continue to choose and pay for private health services. An individual can consult one doctor at his own expense while retaining another under the health service. ${ }^{30} \mathrm{He}$ may pay for a private room in a hospital and either pay for the rest of his treatment or receive it free. However, the Act provides that if space is limited, a health service patient requiring privacy on medical grounds may not be deprived of such accommodation ${ }^{31}$ because another is able to bear

promised that no full-time salaried service would be introduced unless the question were reviewed by Parliament. Hentte Services in Britain (British Information Services, I.D. No. 753 rev.) 9-10 (1948). The NHSA was amended to prohibit the introduction of a full-time salaried service. See NHS (Amendment) A, 1949 \$ 10, 11, 12.

29. See, A National Heaitri Service (Cmp. No. 6502) 47 (1944); and Hill, The Inherent Problems in Planning a National Health Service, 21 THe Social SERVICE REv. 456-8 (1947).

30. See NHS (General Medical and Pharmaceutical Services) Regs. S. I. 1948, No. 506 First Schedule $\$ \$ 5,7(10), 10$. A paying patient may receive private treatment from his doctor even at a health centre supported by public money. NHS (Amendment) A, $1949 \$ 29$ Pt. II p. 29; and 468 H. C. DEB. 594 (5th ser. 1949), and see note 33 infra. Although privately issued prescriptions for drugs and appliances may not be filled free of charge, a patient's right to use other services is not impaired. See, generally, HnI \& Woodcock, The National Health Service 50-2, 96 and app. VI (1949); 465 H. C. DEB. 1161 et seq. (5th ser. 1949).

31. NHSA $\S \$ 4,5(1)$; NHS (Pay-Bed Accommodation in Hospitals, etc.) Regs. S. I., 1948 No. 1490 . At the outset, all existing private pay-beds, approximately $2 \%$ of all hospital beds, were set aside under $\$ 5$ for patients willing to pay the full cost of accommodation and treatment. The charge for a bed, the average cost per bed for the particular hospital, is higher than charges made prior to the Act. This burden on private patients, particularly in an old hospital with relatively high operating costs, has been much criticized. During the first year, most Regional Boards made plans to reduce the number of private pay-beds under $\$ 5$ and to increase the less costly part-payment facilities under $\$ 4$. Only about $1 \mathrm{I} / 2$ per-cent of the total number of beds in Britain are pay-beds. There are approximately as many Section 4 amenity beds. REPORT of THE Ministry of Health, 1949 (Card. No. 7910) 250-1 (1950); 468 H. C. Deb. 567 et scq. (5th ser. 1949); and opinions of anonymous British medical experts reviewing the first year of operation in The National Health Service Act in Great Britain, Practioner 1, 4 (special issue Autumn, 1949) (hereafter cited as Practioner's Review of NHSA); Speech of Blenkinsop, Parliamentary Secretary to the Ministry of Health, $490 \mathrm{H}$. C. DEB. 174-5 (5th ser. 1951). 
the cost. But despite such provisions, ${ }^{32}$ Parliament risked a double standard of medical care-one within and another outside the service. For example, if only lower-income groups had participated, an impression might have resulted that national health service standards did not measure up to private medical care. $^{33}$ But since such a large proportion of the population joined the service,

In spite of some reports that service patients in need of privacy on medical grounds are denied that care in favor of private patients, see, e.g., $472 \mathrm{H}$. C. DEB. 2134 (5th ser. 1950); this provision has not been abused and at least $40 \%$ of the pay-bed blocks are actually occupied by free patients. Speech of Bevan, 468 H. C. DEB. 582-3 (5th ser. 1949).

32. By providing a comprehensive service (NHSA $\$ 1(1), 2,3,16-18,21-9,38-41$; and see note 3 , supra) it was contemplated that no special advantage would be available for those who remained outside the service. Address by Bevan, Minister of Health, in Record of Proceedings at First Annual Meeting of Executive Councils Association (England) National Health Service (hereinafter cited as REcond FIRST ExEcutrve CouncIs' Assoc. MeETING) 47 (1948). In support of NHSA $\S 33(2)$ (b) which allows a service patient to transfer from one doctor to another, it was argued that this would keep fee-paying within reasonable limits and prevent a breakdown of the public service. $422 \mathrm{H}$. C. DEB. 56 (5th ser. 1946). The Act guarantees everyone the free service of a general practitioner. NHSA $\$ 33(2)(c)$. However, because of extreme shortages of personnel and facilities, the government has not guaranteed to provide all services. For a discussion of this problem in the dental service see SeLECT. CoMmitTEE REPORT ON NHS, $1949 \llbracket 16$. But to assure service patients the opportunity of treatment by available professional personnel, the Act leaves no special advantages for a doctor remaining outside the service. It was thus successfully argued that to prohibit private practice of doctors in the service would discourage a great many good doctors who would otherwise join. Speech of Key, Parliamentary Secretary to the Ministry of Health, 422 H. C. DEB. 218 (5th ser. 1946). Likewise, in negotiating rates of remuneration, it was necessary to set rates high enough to maintain the attraction of public service as compared with private practice. Hill, Inherent Problems of Plauning a National Health Service, 21 The Social Service Rev. 456, 461-2 (1947).

33. "[I] would regard any substantial number of private patients as an indication of the failure of the Scheme, because one of the things we have had to fight against is the danger that all we would succeed in doing is create a glorified Poor Law System. . . . I am extremely anxious ... that there shall not be any impression at all of two standards of medical treatment in view, one inside and one outside. . ." Address by Bevan, Minister of Health, Record First Executive Councils' Assoc. Menting 46, 47 (1948); and see 447 H. C. DEB. 47, 76, 77 (5th ser. 1948).

The Central Health Services Council advised the Minister to allow doctors to treat private patients in health centres so long as no distinction between private and public patients was made. The Health Centre Committee reasoned that there would be no economic justification for forcing a doctor to maintain a separate office since less than 1 in 20 of the whole population were private patients. "Further, quite apart from the interests of the individual doctor, the Committee thought it undesirable to perpetuate two places of practice, one public and one private. To do so would suggest that there were two standards of practice." Report of Central Healter Services CouncII, 1949 (HCR 84) \13(a) (1950).

In agreeing to accept this advice, the Minister of Health made it clear that regulations would be issued to prevent the creation of a double standard in Health Centres. 468 H. C. DEs. 573, 591-2 (5th ser. 1949). For Parliament's original stand that public funds should not be used to help doctors obtain private fees see speech of Bevan, 422 H. C. DEB. 448 (5th ser. 1946). 
this danger was apparently averted. ${ }^{34}$ Moreover, pressure of middle class participants for medical care equal to that to which they are accustomed helps maintain high standards. ${ }^{35}$

Freedom of choice, which permits patients to consult doctors in whom they have confidence was never unrestricted. Not only an individual's ability to pay but also the number and accessibility of medical personnel and facilities always limited his choice. ${ }^{36}$ By removing the ability-to-pay limitation, and by preserving the right of the patient to select and to change his doctor within the service, the Act has enlarged freedom of choice for almost everyone. ${ }^{37}$ This is par-

34. See address by Bevan, Record First Executive Councils' Assoc. Meeting 46 (1948). At the beginning of 1950, approximately $95 \%$ of the population had joined the service. Some Statistics on the Natronal Health Service (British Information Services, I. D. No. 1002) 1 (1950).

Private patients are not getting special advantages. For example, despite an extreme shortage of dentists, private work done by National Health Service Dentists (approximately $95 \%$ of all dentists) is less than $5 \%$ of their total work. Though time devoted to care of a private patient usually exceeded corresponding work-time for a Service patient, no significant difference was revealed. REport of the Working PARTy on Chairside Tmas Taken in Carrying Out Treatment for General Dental Practitioners in England, Wales and Scotland (H. M. S. O., No. 32-393) \63(8) (10) (1949); Some Statistics on the National Health Service (British Information Services, I. D. No. 1002) 2 (1950).

35. See speech of Charles Hill, reported in Britis Medical J. 736, 737 (March 25, 1950). The number of persons joining the service in the "wealthier" districts is surprisingly high. Supporters of the National Health Service believe that the wealthier groups, in the habit of demanding and receiving the highest quality of medical care, will insist on high standards in the Service. John G. Hill, Has Britain Shown That Health Insurance Can Work? 23 The Social Service Rev. 435, 439 (1950).

36. A Natronal Health Service (Card. No. 6502) 26 (1944); Ogilvie, The Granny Racket, BritisH Medical J. 683, 684 (March 25, 1950). In rural areas a patient does not take the doctor of his choice but one who happens to settle there. "If I go to an industrial area, what choice have I of a doctor? What we often see is the plate on a corner house . . ., and we go there without any knowledge at all of the doctor." Speech of Davies, 422 H. C. DEB. 251 (5th ser. 1946). For views that the doctorpatient relationships in Britain need improving, not preserving, see, A Natronal Heastr Service (CMd. No. 6502) 37, 38 (1944); 250 The Lancet 503-4 (1946). For similar views of the doctor-patient relationship in the United States, see Spahor, Medicine's Neglected Control Lever, 40 The Yale Rev. 244 (1951).

In the United States freedom of choice is far from absolute. The inability of families receiving low incomes (a third of all United States families had total money incomes of less than $\$ 2,000$ in 1948) to pay for private medical care when needed was first documented nearly 20 years ago by President Hoover's committee on the cost of medical care. Geographically the ratio of doctors to population varies widely and is almost directly correlated with income levels. Low-Incone FanIIIEs and Econonic StabiLity, Sen. Doc. No. 146, 81st Cong., 2d Sess. 15-16 (1950). And see Comment, The Essentials of an Adequate Health Program, 59 YALE I.J. 292 (1950).

37. NHSA $\$ \S 1(2), 33(2)(b)$; NHS (General Medical and Pharmaceutical Services) REGS. S. I., 1948, No. 506, Regs. 14(1), 31. "[S]o far as choice exists now it will go on and the doctor of our choice will [look] after us as personal patients, visit- 
ticularly true since more than nine out of ten doctors and dentists, and virtually all opticians, druggists and hospitals are taking part in the National Health Service. ${ }^{38}$

Although personal means no longer restrict free choice, that choice is still limited by the Nation's budget. As long as hospitals must compete with tanks, houses and schools for appropriations, Britain cannot make sufficient expenditures on the Health Service to meet newly released demand. ${ }^{39}$ But the Act has

ing us at our homes, or we visiting him. ... The great difference will be that we shall not pay fees for attention. We shall pool our resources as a community and pay doctors for our general care, irrespective of our individual needs." Speech of Key, $422 \mathrm{H}$. С. Dев. 214 et seq. (5th ser. 1946). "Both doctor and patient are pleased with their new and easier relationship." 255 ThE LANCET 823 (1948).

"[M]iddle classes are to a very large extent the real beneficiaries of the new Act. The Act is partly the outcome of the gradual social revolution which is taking place in this country. The specialist can no longer afford to give his services to charitable hospitals gratuitously and to recoup himself out of the pockets of his rich private patients. The salaried employee, black-coated worker, professional man, small business man etc. who used to be outside the National Health Insurnace Scheme [see note 11, supra.] can no longer face an illness in the family with equanimity if he has to pay for it." Communication to the Yale LAw Journal from O. Kahn-Freund, Professor, London School of Economics and Political Science, University of London, August 28, 1951.

Until October 1950 a patient could change his doctor without prior notice. Now he must give two weeks notice. This procedure is designed to check over-hasty action by patients whose request for something they do not need has been refused by their doctor. From 3-6\% of the population have been changing their doctors annually for reasons other than change of address. The notice requirement has been formally denounced by the Executive Council's Association as a betrayal of the principle of freedom of choice. Record Third Executive Councin's Assoc. Meeting 20, 91, 102-104 (1950).

38. Id. at 60-1; Some Statistics on the National Health Service (British Information Services, I. D. No. 1002, 1950).

Also see NHSA $\S 38(2)$ (freedom to choose druggists); id. $\$ 40(2)$ (b) (freedom to choose dentists); id. $\$ 41$ (3) (c) (freedom to choose opticians).

39. See, e.g., annual Budget speeches of the Chancellor of the Exchequer $483 \mathrm{H}$. C. DEB. 2082 (5th ser. 1950) and 488 H. C. DEB. 851-2 (5th ser. 1951). For a discussion of these Budgets see 158 EconomIsT 251 (1950); 160 ECoNOMIST 841-2 (1951); and 41 New Statesman and Nation 409-10 (1951). Though hospital facilities are inadequate, building plans were suspended because of a ban on capital consruction. Economic SURVEy For 1950 (CAsD. No. 7915) If 44 (1950) and see 37 New StatesMran and Nation 3-4 (1949). See also speech of Thorneycroft, 465 H. C. DEB. 1099 (5th ser. 1949). In $1950,10 \%$ of each tax pound raised was allocated to the Health Service, $20 \%$ to defense, and a total of $11 \%$ to Local Authorities for education, housing, police, roads, etc. Soctal Service Finance (British Information Services I. D. No. 864 rev.) 2 (1950).

Even within the Health Scheme, one service must compete with another for appropriations. "[I]t is not possible . . . to permit any over-all increase in the expenditure on the Health Services. Any expansion in one part of the Service must be met by economies or, if necessary, by contraction in others." Speech of Sir Stafford Cripps, Chancellor of the Exchequer, reprinted in part $i d$. at 3. For an allocation of funds between the different services see, Civis Estimates Class V 1950-51 (HCP 7-V) 26-41, 129-140 (1950).

The cost of the National Health Service during the first nine months of operation was $40 \%$ above original estimates of 126 million pounds. This increase was due pri- 
made a difference. Everyone now has an equal opportunity to use almost all existing health resources, and heavy costs of illness which formerly hit individual families are shared by all. ${ }^{40}$

Even if the nation's financial resources were unlimited, the Act could not have relieved shortages and maldistribution of health personnel and facilities overnight. ${ }^{41}$ Present delays in medical, dental and hospital treatment and in filling prescriptions for glasses will continue until supply catches up with newly revealed pent-up demand. ${ }^{42}$ Some supporters argued that health services should

marily to the unexpected size of public demand. At the close of the third year, however, annual costs appear to be levelling off at approximately 450 million pounds $(\$ 1,260,000,000)$. Practitioner's Review of NHSA 97-102; Select Consmittee Report on Administration of NHS, 1949 fit 4-13; Civil Estinfate Class V 1950-51 (HCP 7-V) 26, 129 (1950); 160 Economist 419-20 (1951).

40. See speech of Key, supra note 37; and of Bevan, $447 \mathrm{H}$. C. DEB. 48 (5th ser. 1948). For reference to the financial impact of ill-health on the family prior to the inauguration of the Health Service see Refort on tHe British Healte Services (Political and Economic Planning) 410 (1937). A patient discusses the financial relief for the head of a middle-income family using the Service in PRACTITIONER's REviEw of NHSA 96; see also note 33 infra. For a comparison of the cost of hospitalization to a family under the National Health Service with cost to a family under present circumstances in the United States, see 259 THE LANCET 864 (1950). For the hardships of disability on United States families see Comment, Insurance Against Temporary Disability, 60 YALE L.J. 647, 658-62 (1951).

The total cost of the Health Service is not entirely an additional burden on the community. In the main it is a transfer of expense from the private to the public purse. Total cost is approximately $4 \%$ of the national income which is about what Americans spend of their national income for less comprehensive public and private medical care. The First Year of the National Health Service (British Information Service I. D. No. 961) 1 (1950); 24 The Soctal Service Rev. 403 (1950); and statement of Seymour E. Harris in Hearings before a Subcommittee of the Committee on Labor and Public Welfare on $S$. 1106, S. 1456, S. 1581, and S. 1679, 81st Cong., 1st Sess. 152-3 (1949). Because of the voluntary services of 12,000 persons, administration costs for the entire British service are only $2.3 \%$ of the total cost. This compares with the $20-40 \%$ spent on administration by voluntary health insurance groups in America. Speech of Bevan, 465 H. C. Deb. 1177 et seq. The First Year of the Natronal Healtr Service (British Information Services I. D. No. 961) 1 (1950); address by Becker, to American Medical Association Conference 1950, The Problem of Prepaid Medical Care, (UAW-CIO Social Security Dept.) 4 (June 25, 1950).

41. "[W]e are not in statutory difficulties, but in physical difficulties, and no legerdemain or alteration of words on the Statute Books is going to alter physical facts." Speech of Bevan, during debate on shortage of dentists, 465 H. C. DEB. 1176 (5th ser. 1949). And see Practitioner's ReVIEW of NHSA 3-4.

42. See note 44 infra. For statistics and discussions on the extent of shortages and delays see Select Committe Report on Administration of NHS, 1949 II $\pi$ 25, 56(5), (13) (maldistribution of doctors and consequent delays); $i d$. at $50-54$ (inadequate facilities for manufacturing eyeglasses); $i d$. at 5-8, 39, 468 H. C. Deв. 603 et seq. (5th ser. 1949), 475 H.C. DEB. 911 et seq. (5th ser. 1950) (grossly inadequate supply of dentists); 465 H.C. DEB. 1425 (5th ser. 1949) (waiting lists for hearing aids); TEE FIRST YEAR of the Nattonal Health Service (British Information Services I. D. No. 961) 2 (1950) (shortage of nurses to staff existing hospitals). See, generally, REPORT of CENtral Health Services Council, 1949 \ $\llbracket 25-6,47,67$; Record Third Executtve Coun- 
only be introduced in stages as supplies become available. ${ }^{43}$ But the actual extent of demand could not be estimated until the services were offered. To have delayed the introduction of services until adequate supplies became available would have obscured, not altered, the extent of existing need. ${ }^{44}$

crls' Assoc. Meeting 87-96 (1950) ; Report of Ministry of Health, 1949 (Cird. No. 7910) $247,253,257,260,269-72,292-6,301-2$ (1950).

43. "Many persons in Great Britain expressed the belief that ... the first effort should not have included the general practitioner.... [T] have been confused, perhaps inoperative, if the general practitioners were not included in the whole plans from the beginning. ..." RAPPLEYE, op. cit. supra note 24 , at 9 . There are disadvantages to the sudden release of pent-up demand. "The really serious difficulty in this increased pressure on the services, and especially in an unnecessary use of them, is that those badly in need of treatment find a new barrier in front of them: no longer moneybut a queue, some of the members of which are not really as urgently in need of medical care as they are." Lewis \& Condie, The British Social Security Program, 12 J. of Polrtics 323, 343 (1950). And see Practitioner's Review of NHSA 11-12, 37. Some members of the Conservative Party argued for delaying the introduction of a comprehensive health service until more adequate facilities were available. See, e.g., speech of $\mathrm{Sir}$ Lucas Tooth 475 H.C. DeB. 927 (5th ser. 1950) ; of Howard, 465 H.C. DeB. 1134-5 (5th ser. 1949); of Linstead, 460 H.C. Deb. 516 (5th ser. 1949). The Labour Party opposed postponement and argued that more men and women would not be drawn into health professions without the incentive of satisfying work before them. SPEAKER'S HANDBOOK 1949-50 (The Labour Party) 304 (1949). To introduce services in stages "would perhaps be expecting too much restraint from any party in office which would naturally wish to take credit for a large scale scheme of health care. ..." Lewis \& Condie, supra at 343. During the 1950 General Elections all parties claimed credit for the National Health Service. See e.g., radio election addresses of representatives of the Conservative, Liberal \& Labour Parties, 43 The Listener 335, 338, 344 (1950).

The Administration Bill, $\$ 702$, provides for the introduction of benefits by stages as adequate personnel and facilities become available. For a similar approach see Comment, Essentials of an Adequate Health Program, 59 Yale L.J. 292, 309-10 (1950).

44. Precedents upon which the Minister of Health relied in estimating demand proved highly unreliable. For example, demand for dental care turned out to be three and a half times greater than the original estimate which, with a liberal allowance for increased demand, was based on the demand for those services under National Health Insurance. Select Commitree Report on Administration of NHS, 1949 \I 29 and pp. 24-5. Demand for optical care is two and a half times greater than demand under National Health Insurance. Id. $\llbracket 37$. In both of these services the underestimation is attributed to an insufficient allowance for increased demand under free as distinguished from contributory services. Id. $\{38$.

A survey conducted by an independent medical journal revealed: "[T] the service has brought to light untreated illness in the old, in children, and in women. The amount of hitherto undisclosed illness is particularly large in women, many of whom have suffered for years . . . without referring to a doctor." 255 THE LANCET 823 (1948). Average attendance at doctors' offices increased between 25-50\%. "Every account agrees that frivolous complaints are no commoner than before. . ." Ibid. And the demand for hospital treatment is about 3 times greater than before the operation of the Service, 256 The Lancet 159 (1949). See also British Medical J. 737 (March 25, 1950), and Hill, Has Britain Shozen That Health Insurance Can Work?, 23 THE Socral Service Rev. 435, 440 (1949).

Most important of all, revealing the demand made the public and Parliament aware of how widespread the need and how inadequate the facilities. See, e.g., the widely 
Despite these shortages, freedom of choice has been extended. More patients have been treated than if the Plan had not been in operation, ${ }^{45}$ and the spurt in demand has stimulated provision of new medical resources. For example, demand for glasses has within two years caused a $50 \%$ increase in productive capacity. As a result, current production not only meets current demand but is also eating away a huge backlog. ${ }^{46}$ The training of enough dentists, like the training of doctors and nurses, is a long-run problem. ${ }^{47}$ Prior to the war more dentists left than entered practice. This trend is being checked and students in training have almost doubled.48 Apparently there is an adequate

publicized Parliamentary debates on the shortage of dentists, $475 \mathrm{H}$. C. Der. 106 et seq. (5th ser. 1950).

45. Means, supra note 27, at 53-6. For example, during the first year of the National Health Service, more people received dental treatment than had ever before received it in a single year. PrActitroneR's Review of NHSA 54, 60. More out-patients were dealt with in hospitals. In some metropolitan hospitals there was as much as a $40-50 \%$ increase in the number of cases handled. There was a real increase in the number of patients, for the number of attendances per patient did not rise. Id. at 4. RePORT of tae Ministry of Health, 1949 (CMd. No. 7910) 119 (1950). 80,000 old people who never had their eyes tested before the Act and 2,000,000 whose eyes had not been tested during the previous 5 years are now wearing glasses. $472 \mathrm{H}$. C. DEB. 431 (5th ser. 1950). Prior to the passage of the Act, no inexpensive hearing aids nor adequate maintenance facilities were available for the deaf. Within the first 2 years of operation 75,000 aids were issued and 37 distribution centres were opened. $422 \mathrm{H}$. C. DEB. 45 (5th ser. 1946); 475 H. C. DEB. (written answers) 174 (5th ser. 1950); Some Statistics on the National Health Service (British Information Services I. D. No. 1002) 3 (1950).

46. At the end of the first 6 months of the service, the total public demand for glasses increased two and a half times over the demand prior to July 1948. Though production of lenses was increased by about $40 \%$, the average delay in supply was about 4 months and later reached 8 months. Within 2 years, $15 \frac{1}{2}$ million pairs of glasses were prescribed and $14 \mathrm{t} / 2$ million had been supplied. Production is now 33\% above current demand and long delays are almost entirely confined to special lenses. REPORT OF THE Ministry of Health, 1949 (CMd. No. 7910) 293 (1950); address by Sir William S. Douglas, Permanent Secretary to the Ministry of Health in Record of Proceedings at Second Annual Meeting of Executive Councils' Association (England) National Health Service (hereinafter cited as Record Second Annual Executtve Counctls' Assoc. Meetrng) 58 (1949); address by Association President Lesser, id. at 74; address by Sir John A. Charles, Chief Medical Officer of the Ministry of Health in RECoRd ThIRD Annual Executive Counctls' Assoc. Meeting 94 (1950); and 472 H. C. Deb. 433-6 (5th ser. 1950).

Plans have been made to double production of hearing aids to meet demand. 465 H. C. Deb. 1425 (5th ser. 1949).

47. The minimum training time for a doctor is five to seven years, for a dentist four years, and for a nurse three years. Britain 1950-51 (Central Office of Information) 230, 276-7 (1950).

48. See speech of Hill, 475 H. C. DeB. 953 (5th ser. 1950). Before World War II there were between 1300 and 1400 dental students in training at a given time. In 1950 there were 2,135 dental students. 475 H. C. DEB. 274 (written answers) (5th ser. 1950). Compared with a pre-war annual intake of 500 students is the 1950 intake of between 600 and 700. Address by Sir John A. Charles, Chief Medical Officer of the Ministry of Health in Record Third Annual Execurive Councirs' Assoc. Meeting 92 (1950); 
supply of doctors but they are maldistributed. ${ }^{49}$ The training of more doctors, the development of health centres and financial inducements to practice in unpopular areas will eventually afford wider choice, without regimentation of either patient or professional personnel.50

\section{The Problem of Priorities}

As long as shortages continue, a priority system for the distribution of some services is necessary. ${ }^{51}$ For example, a small percentage of hospital beds and of lens production is reserved for emergency cases on medical grounds. ${ }^{52}$ But "political" priorities-based on the government's determination of the comparative potential value to the state of one group over another-had to be avoided. They could endanger the right of individuals to benefit equally from the best available medical care. ${ }^{53}$ For example, services in short supply might

Communication to the YaLE LAw Journal from Elsa E. Wending, Reference Division of the British Information Services, July 13, 1951. From a low of 14,904 dentists in 1949 during the period 1940-1950 the number of registered dentists rose in 1950 to a total of 15,052. Ibid.

49. The annual output of the medical schools is about 2,100 doctors a year, which would maintain the ratio of one doctor to about 1400 persons. There is one general practitioner for about 2,400 people. One general practitioner should be able to care for between 2,000 and 3,000 patients, depending on the doctor's temperament, the geography and other characteristics of his practice. Under the National Health Service a general practitioner is permitted a maximum of 4,000 patients. RAPPLEYE, op. cit supra note 24 , at 27; 255 The LANCET 824 (1948); Hill, Has Britain Shown That Health Insurance Can Work? 23 The Soctaz Service Rev. 435, 441 (1949); NHS (General Medical and Pharmaceutical Service) REgS. S. I., 1948 No. 506 Reg. 13(2).

50. An effort is being made to increase the output of medical schools by 300 graduates per year. RAPpleye, op. cit supra note 24 , at 27 . For a discussion of the importance placed on the development of health centres see Brady, CRISIS IN BrrtaIN 390-392, $392 \mathrm{n}$. 116 (1950); and see note 33 supra.

A certain sum is set aside annually for additional payments to doctors who are willing to practice in sparsely populated or otherwise unattractive areas. By the end of 1949, 57 doctors were receiving 21,000 pounds annually in inducement payments. REMUNERAizon of Doctors Under the National Healtr Service (British Information Services I. D. No. 906 rev.) 3 (1950); address by Sir William S. Douglas, Permanent Secretary to the Ministry of Health, in Record Second Annual Executrve Councils' Assoc. MEETING 57 (1949).

51. See, e.g., speech of Bevan, Minister of Health, 422 H. C. DEB. 45, 46 (5th ser. 1946).

52. For a discussion of the Emergency Bed Service in London and of hospital admission policy and problems see RAPPLEYE, op. cit. supra note 24 , at $22 ; 256 \mathrm{THE}$ LANCET 159 (1949). During the 1950 influenza epidemic, 92\% of all urgent cases were admitted to hospitals within 24 hours through the Emergency Bed Bureau. Reply of Marquand, Minister of Health, 483 H. C. DeB. $294-5$ (5th ser. 1951).

As soon as it became clear that manufacturers could not keep up with the demand for eyeglasses, $5 \%$ and later $7 \% / 2 \%$ of production was allocated to priority prescriptions. 472 H. C. DEB. $433-36$ (5th ser. 1950).

53. "Plato interprets medicine as a form of politics. . . Medical art, he explains, must not consider the prolongation of life as its aim, but only the interest of the state. 'In all properly ruled communities, each man has his particular work assigned to him ...? 
only be granted workers in essential industry, even though other individuals were equally in need of care. Nonetheless the Act's provision of priority dental care for children seems close to a political priority, since, care of a new generation's teeth is preferred over dentures for octogenarians. ${ }^{64}$ This priority failed in operation because high fees set for general service within the National Health scheme attracted dentists away from the lower income earned for child care. $^{55}$ Thus adults were given an unintentional priority over children. ${ }^{50}$ Distribution of free services in short supply, without creating priorities based on factors as inconsistent with the Act's principles as ability to pay or political expedients, remains unsolved. ${ }^{\mathbf{5 T}}$

\section{Protection from Neglect}

Numerous safeguards protect the rights of individuals within the service from abuses by administrators and professional personnel. ${ }^{58}$ The Act provides

[T] he physician has 'no right to treat a man who cannot carry out his ordinary duties, for such a man is useless to himself and to the state'..." 1 Popper, The Open Society AND ITS ENEMTES 121 (1945).

The Minister of Health expressed his awareness of this danger: "It is not possible for a Minister of Health, no matter to what party he belongs to say that any particular class of patients is going to have priority over any other class of patient in the Health Service. It is a wicked thing to say to people who are suffering from cancer that the House of Commons regards the provision of this or that relief to some other class of patient as taking priority over the treatment of cancer. We must not have that sort of psychology in the Health Service. . . It is part of the psychology of sickness that every sick person must feel that he or she is receiving as much attention as any other person." 465 H. C. DEB. 1175 (5th ser. 1949).

54. NHSA $\$ 22(1)$ makes every local health authority responsible for making arrangements for the dental care of children under five and expectant and nursing mothers. For children over five, responsibility for the provision of dental care rests with the educational authorities. $472 \mathrm{H}$. C. DEB. 435 (5th ser. 1950). See REPORT OF THE Ministry of Health, 1949 (CMd. No. 7910) 255 (1950); Practitioner's Review of NHSA 57.

55. Ibid. There has been difficulty in increasing the salaries of dental and medical officers employed by local authorities because any increase in compensation would result in demands from other staff employees. See speech of Baird, 465 H.C. DEB. 1122 (5th ser. 1949). Prior to the National Health Service there was one dentist for every 3,000 children in schools; since its inauguration the ratio has changed to one for every 6,000 . $472 \mathrm{H}$.C. Deв. 433 (5th ser. 1950). For a debate on the grossly inadequate supply of dentists see 475 H.C. DeB. 911 et seq. (5th ser. 1950).

56. For the view that political expediency has prevented the restoration of the priority for children see Practitioner's Review of NHSA 57.

57. See, e.g., 465 H.C.DEв. 1122-76 (5th ser. 1949); and 475 H.C.DEB. 911-51 (5th ser. 1950). Prior to the scheme, some argued that there was no shortage of dentists. " $[T]$ here is a financial enforced priority for dental treatment, and the workers still cannot afford good dental treatment. Therefore, there is a service available of competent dentists to treat patients who can afford to pay for their services." Speech of Baird, 447 H.C. DEB. 103 (5th ser. 1948).

58. "[The Health Act] has come into existence for the benefit of the patient. The professions are able to organize pressure groups of various kinds, and to make their demands articulate, but the general mass of patients has to depend upon you [Executive Councils' 
for lay representation on almost all administrative committees and for the investigation of any complaints. ${ }^{59}$ In the event of injury suffered under public treatment, a patient may sue the Ministry of Health. ${ }^{60}$ Through his Member of Parliament an individual may question the Minister of Health in the House on the administration of the National Health Service. ${ }^{61}$ Finally, the right to vote retains basic control in the hands of the public.

Assoc.], and has to depend upon the House of Commons, and has to depend upon the Ministers for the safeguard of their position." Address by Bevan, RecoRD FIRst Executrve Councils' Assoc. Meetring 41 (1948).

There has been little evidence of abuse by the 50,000 individuals providing service. At the end of the first 15 months only 382 had been called before disciplinary committees. Of these cases 190 were dismissed. THE FIRST YEAR of the National Health Service (British Information Services I.D. No. 961) 1 (1950) ; and see speech of Bevan, 465 H.C.DEB. 1179 (5th ser. 1949). For a detailed compilation of more recent disciplinary cases see note 156 infra.

There has been some abuse of the Service by the public as well. Unnecessary resort to doctors to obtain a prescription for free aspirin has not been uncommon. To discourage this, the Act was amended to permit a nominal charge for all prescriptions. The Ministry has not imposed this tax, primarily because it would place an unfair burden on largefamilies, and exemptions would create administrative difficulties. However, the publicity accompanying the proposal has caused a reduction in the number of such cases. SELECT Comaittee Report on Administration of NHS, $1949 \pi \pi 41-4,56(10)$ ) 470 H.C.Deb. 503-4 (5th ser. 1949); NHS (Amendment) A, 1949 \$16; 470 H.C. DEB. 2265 (5th ser. 1949).

59. See notes 141-82 infra and text. In addition to representation on statutory bodies, much of the administrative work in the day-to-day operation of hospitals and clinics is undertaken by committees of voluntary helpers. "It is the biggest voluntary scheme ever introduced; localized democratic control in medical planning means that the people of Britain and their doctors tackling their health problems together on the spot." Letter from Dr. J. M. MacKintosh, University of London, to the Editor, 23 THE SocIal Service REv. 252-3 (1949); note 40 supra. For similar views expressed by Lord Pakenham, see 157 ThE ECONOMIST 61 (1949).

60. NHSA §13. The Act makes Regional Boards, Boards of Governors, and Hospital Management Committees corporations responsible as principals in all legal actions (including liabilities in tort) involving their respective functions and deprives them of any Crown privileges, except for the right of the Crown to withhold documents on grounds of public policy. But see speech of Bevan, 428 H. C. Des. 1080 (5th ser. 1946) : "It ought always to be possible to have the relevant documents produced in any action whatever, and they ought to be withheld only in very exceptional circumstances."

Cf. Cassidy v. Ministry of Health, 1 Times L. R. 539 (C. A. 1951). The Ministry of Health was substituted as defendant and held liable for the negligent treatment of a hospital patient prior to the National Health Service. The doctor responsible was employed and paid by a hospital which had been claimed by the Minister under the Act. Apparently, if a patient engages his own surgeon privately, the Ministry (or a hospital authority) will not be held liable. Id. at 549-50. See, generally, WrLlams, Crown ProCEediNGS, 21-7, 30-7 (1948).

61. An excellent method of holding a Ministry to its responsibility is the use of questions. All members of the House of Commons have the right to ask questions of Ministers on four of the five days in a Parliamentary week. Questions are asked on about 150 days annually. Every member has the right to ask as many as 3 questions for oral answer each day and as many questions as he wishes if the answer is to be written. An average of 


\section{Rights of the Doctor and the Natronal Health Service}

While acknowledging that ultimate responsibility for providing a public service rests with a Minister answerable to Parliament, the government recognized the necessity of an effective voice for doctors in the administration of their own profession. ${ }^{62}$ Underlying this recognition of the need for limited professional self-government was a desire to allay any fears that a doctor's personal freedom would be destroyed, to prevent encroachment on professional freedom, and to encourage full participation by all professions in the service. ${ }^{03}$ Provisions of the Act and regulations relating to professional representation, entry into the service, methods of payment, investigation of complaints, and disciplinary procedure are designed to achieve these interrelated objectives.

\section{Professional Representation}

Anxious to avoid the creation of a new body of civil servants, the government was equally anxious to avoid the opposite danger of syndicalism. The Act attempts to strike a balance between these extremes, without sacrificing lay control, by creating a central advisory committee of all interested professions and by giving them representation on administrative bodies with executive responsibility. ${ }^{64}$

Central Health Services Council. As the conduit of professional opinion, a Central Health Services Council serves the Minister of Health in a consultative and advisory capacity. ${ }^{65}$ More than half of the Council's 41 members are from

70 to 100 oral and an equal number of written answers are given each day. There is a real investigating and disciplinary power in the questions which may concern any matter of public importance within the authority of the government. Questions are usually asked on notice. Finer, Congressional Investigations: The British System, 18 U. of CHI. L. REv. 521, 526-9 (1951) ; Ridges, Constitutional Law 92-3 (8th ed., Forrest, 1950). During a week chosen at random, nine oral questions and three written questions concerning the operation of the National Health Service were answered. 472 H. C. DEB. 906, 1237-42, and (written answer) 66-7 (5th ser. 1950).

The Minister of Health has expressed a willingness to discuss, at any time with any Member of Parliament, any individual cases, concerning the Health Service. Speech of Marquand 483 H.C. DEB. 291 (5th ser. 1951).

62. See A National Healtr Service (Cud. No. 6502) 12, 13 (1944) and speech of Bevan, 422 H.C. DEB. 52 (5th ser. 1946). The Minister of Health has been vested with default powers which give him control over the administration of the service. If an administrative body fails to carry out its functions, the Minister may take over its duties directly. NHSA § 57 .

63. See note 32 sipra, A National Health Service (CMd. No. 6502) 27, 47-50 (1944); and 447 H.C. Deb. 35 et seq. (5th ser. 1948). Also see 250 The LANCET 421-24 (1946) for an interesting discussion of professional participation in a national health service.

64. Speech of Bevan, 422 H.C. DeB. 52 et seq. (5th ser. 1946); and see, generally, BRADY, CRISIS IN BRITAIN 373-90 (1950). "[T]he syndicalists visualize a society in which each industry is collectively managed by the workers . . engaged in producing its particular goods or services." 14 ENCY. Soc. Scr. 496 (1948).

65. NHSA § 2, A National Health Service (Card. No. 6502) 13, 48 (1944). 
the medical profession. Dentists, druggists, nurses and persons with experience in hospital management, local government and mental health services complete the membership. The heads of the six principal medical organizations become members automatically. The others are appointed by the Minister, but only after consultation with representative organizations. ${ }^{66}$ Council members regard themselves, however, as confidential advisers to the Minister and not as delegates reporting back to their organizations. ${ }^{67}$

Maintenance of high standards of care as well as of personal and professional freedom requires constant re-evaluation of the service in the light of advances in knowledge. ${ }^{6 s}$ Thus, the Health Council studies and advises on specific questions raised not only by the Minister, but also on its own initiative. ${ }^{69}$ Cooperating with the Council are various Standing Committees of experts for each branch of the Service. ${ }^{70}$ They engage in active and continuous appraisal of the program's operation and promote controlled experiments in both the science and administration of health care. ${ }^{71}$ Diring the first 18 months, the Minister submitted 30 major policy questions for the consideration of the Council and

66. NHSA, First Schedule I1. The Central Council elects a Chairman from its members and determines its own procedure, Id. at First Schedule $\{5$.

67. Report of Central Health Services Council, 1949 (HCR 84) If 4 (1950).

68. A National Healte Service (Caid. No. 6502) 13 (1944). For an American view see Quality of Medical Care in a National Health Program, 39 Am. J. of Public Healt 898 (1949) reprinted in Hearings before a Subcommittee of the Committee on Labor and $P_{n b l i c}$ Welfare on S. 1106, S. 1456, S. 1581, and S. 1679, 81st Cong., 1st Sess. 588,604 (1949).

69. NHSA $\S 2(1)$; and see speech of Key, 425 H.C. DeB. 1784 (5th ser. 1946). "We have ... taken it to be our task not only to consider specific requests for advice from the Minister, but to review the general development of the Health Service and to study any matter to which, in our opinion, the Minister's attention should be called. We are required by the Act, however, only to advise on 'general' matters; we consider that this limits us to matters of broad general policy and removes all questions of detailed administration from our terms of reference." Report of Central Health Services Councin, 1949 (HCR 84) $\llbracket 2$ (1950).

70. NHSA \$2(3), (4) and speech of Key, 425 H.C. Des. 1786 (5th ser. 1946). The Minister, after consultation with the Central Council, may constitute Standing Advisory Committees to advise him and the Central Council. The Minister has undertaken not to act, except in emergency, on any Advisory Committee report until the Council has had an opportunity to express its views. The Council is responsible for coordinating the work of all Committees to ensure that the central advisory system works as a whole, not as a number of disjointed parts offering unrelated advice to the Minister. The Council was divided on whether all Committees should have both professional and lay representation. A narrow margin favored such lay representation but the Minister rejected this advice. He maintained that he should be able to look toward Committees, such as the Medical, Dental, and Pharmaceutical, for solely technical advice and that questions affecting these services as a whole should be discussed in full council. REPORT OF THE CENTRAL Health SERVICEs CounCIL, 1949 (HCR 84) fit 5-7 (1950).

71. See reports of the Standing Advisory Committees, id. โा 32-78. For example, the Council has appointed a Committee to consider whether existing arrangements for engaging in general practice under the Health Service enable doctors to provide the best possible standard of service. The Committee is to give advice on, for example, the range of work and standards of practice which should be expected both by the public and the medical 
Committees. In addition, the Council advised the Minister on more than a dozen policy matters which it thought important. Most of the recommendations made in its Annual Report to the Minister were accepted, including one which was given effect by amending the Act itself. ${ }^{2}$ Criticisms of the Service, whether or not acted on by the Minister, become available for public consideration in the Council's Annual Reports. ${ }^{73}$ Thus, through a central advisory system, doctors are given an effective voice in overall policy.

Regional Hospital Boards. Though financed nationally, all hospital and specialist services within the Health Scheme have been regionally pooled. Each area is centered on a medical university ${ }^{74}$ and administered by a Regional Board. ${ }^{75}$ To ensure professional, community, and governmental representation on each Board, the Minister consults with university, medical, and other regional organizations before appointing members. ${ }^{\mathbf{7 6}}$ In practice, however, control appears to rest in the medical profession.77

To safeguard academic freedom, teaching hospitals in most areas are independent of the Regional Boards. ${ }^{78}$ These hospitals are each administered by

profession, entry into general practice, method of remuneration, and liaison with hospital and specialist services. 260 THE LANCET 104 (1951).

72. Statement by the Minister of Health, Report of the Central Healte Services Councrn, 1949 (HCR 84) ii-iv (1950). NHS (Amendment) A, 1949 \$29 pt. II p. 29.

73. NHSA $\S 2(5)$. The Minister is required to publish the Report unless, after consultation with the Council, it is decided to be in the public interest to withhold the report.

Outside the Council freedom of criticism is retained. All doctors are free to publish their views on the organization and administration of the Service. See 447 H.C. DEB. 48, 49, 57, 58 (5th ser. 1948) and Health SeRvices in Britarn (British Information Services, I.D. No. 753 rev.) 10 (1948).

74. NHSA §§54-6; Report of the Ministry of Health, 1949 (Cand. No. 7910) 245 (1950); Select Committee Report on Administration of NHS, 1949 If 46, 48.

75. NHSA $§$ 11-15. Each Regional Hospital Board must make hospital and specialist services available to all persons in its area, review existing resources and assess the need for improvements. Id. at $\$ 12(1)$. See also NHS (Functions of Regional Hospital Boards etc.) REGs. S.I. 1948 No. 60 pts. I, II.

76. NHSA Third Schedule pt. I, and speech of Bevan, 422 H.C. DeB. 50 (5th ser. 1946). Some Members of Parliament proposed that Regional Board members be elected, not appointed. However, the government argued for their selection not only as geographic representatives, but also for their knowledge of hospital needs and problems. See, e.g., speech of Messer, $i d$. at 139-45; speech of Key, id. at 210. Provision is made to reimburse Board members for loss in earnings and traveling expenses, because it would be "improper if very many people with long experience of hospital administration and local government organisation were unable to serve upon these boards because they could not afford to do so." Speech of Bevan, 425 H.C. DEB. 1702 (5th ser. 1946). NHSA Third Schedule pt. IV $\llbracket 2$ (c) as amended by NHS (Amendment) A, $1949 \$ 29$ pt. I p. 26.

77. "[T] he membership of the regional boards ... showed 26 per cent from local authorities, 21 per cent from the voluntary hospital field, 20 per cent from the medical profession, and 15 per cent from the universities. Part of the first group and all of the last three groups are drawn from the medical profession." BRADY, CrISIS IN Britain 381 n.78 (1950).

78. Means, supra note 27, at 55. In Scotland teaching hospitals are under Regional Hospital Boards. Select Comimittee Report on Administration of NHS, 1949 đ 46. 
a Board of Governors of whom the Minister may appoint fewer than half. Control, therefore, rests with members chosen by the university, the hospital staff and the Regional Board. ${ }^{79}$

To secure maximum decentralization, Regional Boards must appoint Hospital Management Committees to supervise the day-by-day operations of particular hospitals. ${ }^{80}$ The Board appoints these Committees after consultation with the hospital's senior staff, the Local Executive Council, and local health authorities. $^{\text {sI }}$ Boards and their subsidiary Committees are corporate legal entities. ${ }^{\$ 2}$

Though the Minister of Health has ultimate control of administration, his policy has been to exercise his power infrequently. ${ }^{83} \mathrm{His}$ regulations, which must be laid before Parliament, ${ }^{84}$ have outlined in broad terms the division of responsibility between Regional Boards and Management Committees. Flexibility and local independence have thereby been encouraged without sacrificing advantages of regional planning. ${ }^{85}$

Local Executive Councils. Administration of general practitioner services is highly decentralized and almost professionally self-governed. The Act created a Local Executive Council for each county and county-borough. ${ }^{86}$ Each Council has 25 members, including seven physicians, three dentists and two

79. NHSA $\$ \S 11(8), 12(3)$ and Third Schedule pt. III. Some members are chosen after consultation with local health authorities in the region. For the functions of the Board of Governors see, NHS (Functions of Regional Boards etc.) REcs. S.I. 1948, No. 60 pt. IV.

80. NHSA $§ 11(3),(6), 12(2)$; Select Committee Report on Administration of NHS, $1949 \Uparrow 47$; speech of Bevan, 428 H.C. DEB. 1078 (5th ser. 1946); NHS (Functions of Regional Boards etc.) REGS. S.I. 1948 No. 60 pt. III.

81. NHSA Third Schedule pt. II. For a discussion of Local Executive Councils see notes 86 to 96 infra and text.

82. NHSA $\S 13$.

83. Report of the Mintstry of Health, 1949 (CMD. No. 7910) 243, 245-6 (1950); Select CommitTeE RePort on Administration of NHS, 1949 Tा 46-55. For discussion of the problem of reconciling central financial control with local autonomy by means of local budgeting, see 157 The Economist 180, 934 (1949); British Medical J. 736 (March 25, 1950) ; 159 The Economrst 5-7 (1950); and speech of Dr. Hill, 490 H.C. DEB. 146 (5th ser. 1951).

84. NHSA §75. Most regulations are valid as soon as placed before Parliament but are subject to amendment by resolution of either House within 40 days. Some regulations go into effect only after approval by resolution of both Houses. Speller, The Nationaz Healte Service Act, 1946120 (1948). Some opposition was focussed on the broad authority delegated to the Minister in the regulation provisions of the Act. Hill, The Inherent Problems of Planing a National Health Service, 21 The Soctar Service Rev. 456, 469, 471 (1947).

85. See, e.g., NHS (Functions of Regional Boards) REgS. S.I. 1948, No. 60; REPORT of the Ministry of Health, 1949 (Curd. No. 7910) 243 (1950); and speech of Bevan, 425 H.C. Deb. 1816 (5th ser. 1946). See also, National Health Service, The Developaient of Consultant Services (S.O. No. 32-394 TIT 7, 14 (1950).

86. NHSA §31. Under the Act, 163 Executive Councils were established. SELEct Committee Report on Administration of NHS, 1949 ๓ 46. 
pharmacists appointed by Local Committees representing the respective professional organizations. ${ }^{87}$ Of the remainder, five members are appointed by the Minister and eight by the local health authorities. ${ }^{88}$

Local Councils are responsible for making and supervising contracts of service with family practitioners and for hearing disputes between doctor and patient. $^{89}$ On certain professional matters, the Council may not act without consulting wholly self-governing Local Committees. ${ }^{90}$ In addition, an Executive Council must establish Medical, Dental and Pharmaceutical Service Committees, composed of lay and professional members, to investigate complaints brought by a patient. ${ }^{91}$ The Executive Councils have also set up an Association which meets annually. This Association serves as a channel of communication between Local Executive Councils, thus providing a means of checking the central authority. ${ }^{92}$

87. For example, a Local Medical Committee might be organized by a branch of the British Medical Association. Local Medical, Dental, and Pharmaceutical Committees are recognized by the Act, and given important duties. NHSA $\$ \$ 32,34(3)$ and Fifth Schedule 1 (c), (d), \& (e); and see Brady, Crisis in Britain 388-9 (1950).

88. NHSA Fifth Schedule as amended by NHS (Amendment) A, $1949 \S 29$ pt. I p. 27. Originally this Schedule gave the Minister power to appoint the chairman of Executive Councils; the amendment gives each Council the power to elect one of its members chairman. See 465 H.C. DEB. 1073 (5th ser. 1949).

89. NHSA $\$ \$ 31,33,34(8), 42(1)$, (3), (5). The creation of the Executive Council, an entirely new body, coterminous with the local health areas, was to allay professional fear of being placed under contract with a local government authority and under the supervision of a medical officer of health who is an "administrative doctor." 422 H.C. DEB. 52 (5th ser. 1946). The Executive Council is the employing authority, but it is not the selecting authority (the Medical Practices Committee) for doctors in an area. Id. at 212. Executive Councils are also responsible for the supervision of the dental, pharmaceutical and optical services. NHSA \$\$38-41. See, generally, SeLEct Committee Report on Administration of NHS, 1949 If 14, 17, 18, 26, 31, 43, and pp. 62-64. For a discussion of the role of Executive Councils in the settlement of disputes see notes 146 to 165 infra and text.

90. NHSA $\$ 32(2)$; note 87 supra. For example, after consultation with a Local Medical Committee, an Executive Council may on the basis of an investigation of a doctor's conduct limit the number of persons he may accept for treatment under the health service. NHS (Service Committees and Tribunal) Regs. S.I. 1948, No. 507 Reg. 6(a); see also id. at Regs. 5(2) (b), 13(1), 15(1), 17 (1).

91. Id. at Regs. $3(1), 4,5$. A Service Committee has a chairman and six members. Three are appointed by and from the lay members of the Council and three by the Local Committee of the profession concerned. The Chairman is appointed by the 6 members; in the event of deadlock by the Council. Id. at Reg. 3(2), (3).

92. "It is . . . all to the good that the Executives have found it wise to form an Association ... because unless you can establish effective contact with each other you will have no means of learning from each other's experience and, what is as important to you, you will have means of effectively checking the behaviour of the central authority (laughter) because if you have no means of inter-communication he will be the only person who will know what is happening over the whole thing and he will have you at a disadvantage." Address by Bevan, Minister of Health, Record First Executrve Councils' Assoc. Meeting 37 (1948). 
Other representative bodies. Though family practitioner services are the concern of local bodies, three central units were established to handle national problems. A Medical Practices Committee, composed primarily of practicing physicians, supervises the entrance of doctors into the service. ${ }^{93}$ A Dental Estimates Board of nine members, seven of whom are dentists, scrutinizes estimates of complex dental work performed on a fee for service basis. ${ }^{94}$ Finally, a Tribunal with legal, lay, and medical representation hears cases involving the dismissal of practitioners from the service..$^{95}$

In short, at all levels of organization-central, regional, and local—adequate outlets for professional participation in the administration of the health service have been provided without relinquishing public control.96

\section{Entry into Service-Problem of Maldistribution}

Although government direction might have achieved an adequate distribution of doctors, Parliament rejected this means of accomplishing a basic objective as in conflict with guiding principles of the Act. Moreover such action was impractical, since doctors might decline to join the Service. ${ }^{97}$ Parliament decided therefore, that doctors, like anyone else, should be free to work whereever they preferred. But Parliament refused to accept the contention of the

In addition to the English, Welsh and Scottish Associations, The Joint Committee of Associations of Executive Councils has been formed to permit all three associations to confer on matters of common interest and to act on legislative and administrative proposals of general interest. Constitution of the Joint Committee in REcoRd SECond Execurive Councils' Assoc. Meeting 48 (1949).

93. NHSA $\S 34(2)-(9)$. Of the Committee of 9,7 ( 1 of whom is chairman) must be medical practitioners. Five must be actively engaged in medical practice. $I d$. at Sixth Schedule; speech of Key, 422 H.C. Deb. 211-13 (5th ser. 1946). See also notes 97 to 106 infra and text.

94. NHSA $\$ 40(2)$ (d), (e); Select Comamttee Report on Administration of NHS, $1949 \llbracket 33$. See also notes 124-35 infra and text.

95. NHSA $\$ 42$ and Seventh Schedule, as amended by NHS (Amendment) A, 1949 $\$ 20$. See notes 166-79 infra and text.

96. Of all the American proposals, the Administration Bill offers the most equitable representation of the public and the professions on policy-making and advisory bodies at Federal, State, and local levels. See S. 1679 \$\$ 731-5, 741-2, 751-5; Comment, Essentials of an Adequate Health Program, 59 YALE L.J. 292, 316-18 (1950).

97. See notes 29 and 49 sipra; Select Conmmitee Report on Administration of NHS, 1949 p. 9; 422 H.C. DEb. 218, 260 (5th ser. 1946); and debate following the large-scale campaign carried out in opposition to the Act by the British Medical Association because of fears that the government intended to make doctors civil servants. 447 H.C. Deв, 35 et seq. (5th ser. 1948). But on the eve of "vesting day," Dr. Guy Dain, Chairman of the Council of the British Medical Association, declared: "The fight is over, the public, after July 5 will get the very best service that doctors can give. ... The negotiations with the Minister of Health and his department have resulted in protection of the freedom of the public and the medical profession in most of the things which doctors have thought to be most important." Reprinted in BradX, CRISIS IN BRTtAin 389-90 (1950). 
British Medical Association that every doctor was entitled to take part in the Service by right. This would have compelled the Minister to spend public funds in areas not requiring an additional doctor even though other areas had less than a minimum number. ${ }^{98}$ Such pressure would be justifiable only if the Act gave the State a complete monopoly of medical services. ${ }^{99}$ It does not. A doctor may practice privately anywhere. ${ }^{100}$ Furthermore, the Act entitled every doctor to participate at the location of his previously established practice, if prior to its operation he applied to join the Service. ${ }^{101}$ As a restilt the ratio of doctors to patients continues to differ greatly in each Executive Council area. ${ }^{102}$

Apart from monetary inducements, ${ }^{103}$ the only statutory authority to alter maldistribution is the Medical Practices Committee's power to refuse any application by a doctor to practice for the Service in areas designated by the Committee as "over-doctored." It is the only ground on which the Committee can refuse an application. This is called "negative direction." ${ }^{104}$ In the event

98. See speech of Key, 422 H.C. Deb. 211-13 (5th ser. 1946); Brady, Crisis in Britaid 384 (1950); Hill, Inherent Problems in Plaming a National Hcalth Service, 21 The Social Service Rev. 456, 465-6 (1947); A National Healtu Service (Caid. No. 6502) 27 (1944). For the contention that "[i]t would lead to a hopeless state of affairs should a number of doctors greatly in excess of the needs of the population be allowed to squat in an area where there would be no opportunity for them to build up substantial practices and maintain a proper standard of living", see REcoRd THIRD Executrve Councils' Assoc. Meeting 115 (1950).

99. See, e.g., speech of Key, 422 H.C. DEB. 211-22 (5th ser. 1946); cf., speech of Dr. Taylor, 447 H.C. DeB. 73, 74 (5th ser. 1948). For a contrary view see speech of Colonel Stoddard-Scott, 422 H.C. DEB. 365 (5th ser. 1946).

100. The Act does not apply to a doctor who chooses to remain outside the Service, nor does it contain provisions restricting the area of private practice of a Service doctor. However, specialists who remain outside the Service are excluded from all National Health Service hospitals while specialists in the Service may use these hospitals for their private patients. NHSA $\$ 5(2)$; 425 H.C. DeB. 1780 (5th ser. 1946). For debate during an unsuccessful attempt to amend this provision see 468 H.C. DEB. 648-55 (5th ser. 1949). But non-Service specialists do have operating and other hospital facilities in Nursing Homes, all of which were disclaimed by the Minister. Ibid.; note 21 supra. And see NHS (Amendment) A, $1949 \S \S 10-12$.

101. NHSA $\$ 34(1)$ and 422 H.C. DEB. 54 (5th ser. 1946).

102. Select Committee Report on Administration of NHS 1949 \25.

103. "A certain sum [Special Inducement Fund] is set aside each year for additional payments to doctors in areas which are, in the opinion of the Minister, after consultation with the Medical Practices Committee, sparsely populated, or, for any other reasons unattractive to medical practitioners. . . By the end of 1949,56 doctors were receiving such payments." Remuneration of Doctors Under the National Health Service (British Information Services I.D. No. 906 rev.) 3 (1950); note 50 supra.

104. NHSA $\$ 34(3)$, (4), \& (8). And see Select ConMrtute Report on Adarministration of NHS, 1949. The Second Report of the Medical Practices Committee indicates that the number of under-doctored areas has diminished. RECORD THIRD ExECUtrve Councris' Assoc. MeEting 89 (1950). For categorization of areas by doctorpatient ratio see $i d$. at 114 . 
of a vacancy due to death or retirement in an established practice any doctor may apply for that practice. The Medical Practices Committee, after consultation with the Local Executive Council, fills the vacancy in accordance with relative qualifications of candidates. ${ }^{105}$ Special consideration must be given, however, to such matters as preferences of remaining partners and the family ties of applicants. ${ }^{106}$

Any doctor whose application has been refused by the Medical Practices Committee may appeal to the Minister of Health. The appellant, the Committee, and, in cases involving a vacancy, the doctor whose application was granted, are entitled to be heard. All parties may be represented by counsel. ${ }^{107}$ Pending such an appeal, the Committee's determination is held in abeyance.

Despite strong BMA opposition, Parliament prohibited the sale of medical practices by doctors joining the service. Prior to the Act, a young doctor usually purchased a practice and good will from one about to retire. It was argued that proper distribution in itself kills the sale and purchase of practices and to allow a new doctor to enter the Service where he purchased a new practice would not relieve mal-distribution. To prevent undue hardship and to encourage joining the Service by vesting day, all practicing physicians so entering the Service became eligible for compensation for loss sustained because of an inability to sell their practices in the future. A sum of 66 million pounds was set aside for this purpose. NHSA $\$ \$ 35,36,37 ; 422$ H.C. DeB. 53-4 (5th ser. 1946); 425 H.C. DEB. 1947 et seq. (5th ser. 1946) and 447 H.C. Deв. 39 (5th ser. 1948). "The new system will give the doctor much greater freedom of movement than he has had in the past, without having to buy a practice, to sell it when he wants to go somewhere else, and then to buy another in the place to which he wants to go." Speech of Dr. Taylor, id. at 74. See, generally, Brady, Crists in Britain 384-5 (1950); 250 The LANCET 19-20 (1946).

Moreover a pension scheme has been established to give doctors additional financial security. "A doctor contributes six per cent of his net annual receipts . . and the Exchequer contributes eight per cent of these receipts. In return, after a qualifying period ... a doctor will be entitled to a wide range of benefits including (after five years) a lump sum on death or on retirement after the age of sixty or on incapacity, and (after ten years) on retirement, a pension and lump sum, and on death, a death benefit and a widow's pension, the amounts depending on the number of years for which he has contributed." Remuneration of Doctors under the Natronal Healte Service (British Information Services I.D. No. 906 rev.) 4 (1950); and see NHS (Superannuation) REGS. S.R. \& O. 1947, No. 1755 Reg. 39; NHS (Superannuation) (Amendment) REGS., 1949 No. 1467.

105. NHSA $\$ 34(1)$, (3); Select Commitree Report on Administration of NHS, III 26,27 , and pp. 10, 74, 75 .

106. NHSA $\S 34(9)$ and 428 H.C. DEB. 1159 (5th ser. 1946).

107. NHSA $\S 34(6)(7)(8)$; NHS (General Medical and Pharmaceutical Services) REGS. S.I. 1948, No. 506 Regs. 9, 10. Notice of appeal must contain a concise statement of the facts and contentions. The Minister is not required to provide a hearing if he considers the appeal can properly be determined without one. Id. at Reg. 10(2) (3).

During the first nine months of operation the Medical Practices Committee granted 784 applications. Of these there were 92 in which the applicant had to be selected from a number of candidates for an advertised vacancy. Of 20 appeals made to the Minister 1 was allowed, 15 dismissed, 2 withdrawn and 2 were under review. REPORT of THE Ministry of Healte, 1949 (CMid. No. 7910) 265-6 (1950). 
As a result, patients have been left withuut a doctor for as long as 120 days, hardly an expeditious procedure. ${ }^{108}$

Effective demand, more adequate facilities for doctors in urban as well as rural areas, and the training of more doctors should in the long run ensure adequate distribution. Meanwhile queues for examination, delayed treatment, and over-work of physicians will continue. ${ }^{100}$ Yet doctors have not been deprived of their personal freedom to choose or change their place of practice.

\section{Methods and Rates of Pay}

Originally the Act contained no details concerning methods of payment. Parliament intended to provide a wide area for negotiation between the Minister of Health and representatives of the respective professions. ${ }^{110}$ Recently

108. NHSA § 34(7); Select Comamittee Report on AdMinistration of NHS, 1949 II 27 and pp. 74-5. "[M] eans will be found to facilitate the filling of vacancies without unnecessary restriction on the freedom of the doctor to practice in the area of his choice, and at the same time to provide safeguards to which practitioners in an adequately doctored area feel they are entitled if they are to earn a reasonable living." Speech of Lesser, in Record Second Executrve Councils' Assoc. Meetratg 73 (1949). New regulations in Scotland have revised the procedure for filling vacancies. Selection of a successor is entrusted to the Executive Council after consultation with the Local Medical Committee, subject to appeal to the Scottish Medical Practices Committee. The English Executive Council has recommended the introduction of this new procedure. RECoRD Third Executive Councils' Assoc. Meeting 13, 14 (1950).

109. Select Connittee Report on Administration of NHS, $1949 \llbracket 25,27,56(5)$.

110. See speech of Bevan, 428 H. C. Deb. 1122-5 (5th ser. 1946). If negotiation fails, disputes over rates of pay and conditions of service may be referred to arbitration under NHS (Amendment) A, $1949 \S 13$. This Section brings such disputes within the scope of the Conciliation Act, 1896, 59 \& 60 VIcr., c. 30 and the Industrial Courts Act, 1919, 9 \& 10 GEo. 5 , c. 69. "[C]onsent of both parties to the dispute is necessary before the matter at issue can be referred to arbitration. Awards under these two Acts are not legally binding on the parties, but the fact that both parties ... have agreed to refer the matter to arbitration is an earnest that they intend to abide by the result. In practice the awards are almost invariably accepted even when the parties have not committed themselves beforehand to do so.

"The requirement of consent means, however, that a reference to arbitration under the Conciliation Act and the Industrial Courts Act could be prevented by one of the parties to the dispute. This does not necessarily mean that arbitration in some form or other would not result. The nature and extent of the dispute might be such that some other method of dealing with the matter might be more appropriate, e.g., it might be felt that the issues at stake should be investigated and reported upon by an ad hoc committee of enquiry with a broader composition and wider terms of reference than an Arbitration Tribunal.

"As matters stand at present, therefore, the Minister could not without his consent be taken to any form of arbitration about the fees of general practitioner doctors or dentists in the National Health Service, nor, subject to what is said above, would he be bound to accept the award in a dispute about such fees which did go to arbitration." Communication to the YALE LAw Journal from R. Dempsey of the Ministry of Health, May S, 1951. And see 465 H. C. DEb. 1084 (5th ser. 1949) and 157 The Economist 15 (1949).

For a discussion of the negotiations which have taken place between the Minister of Health and the British Medical Association see Remuneration of Doctors under THE 
the statute was amended to prohibit full-time salaries for general practitioners and dentists. ${ }^{111}$ This amendment was passed to mitigate fears of the dental and medical organizations, who contended that salaries would reduce doctors to servants of the state and cause them to lose their professional freedom. ${ }^{112}$

Capitation fee: All general practitioners are paid either by capitation fee alone or by a reduced capitation fee plus a fixed annual payment. ${ }^{113} \mathrm{~A}$ capitation fee is payment according to the number of patients on a doctor's list. This method purports to maintain a doctor's incentive by rewarding him for zeal, and leaves the patient free to change his doctor. ${ }^{114}$ The fixed payment is intended to aid the young doctor with few patients during his first lean years, and the rural doctor with a small practice and a large area to cover. ${ }^{115}$ General practitioners are free to choose either method of payment. But if they select basic salary plus reduced capitation fee, they must obtain the consent of a Local Executive Council which in turn consults the Local Medical Committee. Appeal may be made to the Minister. ${ }^{116}$

National Health Service (British Information Services I.D. No. 906 rev.) 4, 5 (1950); and 447 H. C. DEB. 35 et seq. (5th ser. 1948).

111. NHS (Amendment) A, $1949 \$ \$ 10,11$.

112. See note 28 supra. And see e.g., A National Health Service (Cad. No. 6502) 27 (1944); 428 H. C. Deb. 1126 (5th ser. 1946); 447 H. C. Deb. 42, 58, 60, 147 (5th ser. 1948); 465 H. C. Deb. 1072, 1082 (5th ser. 1949); Report of the Ministry of Health, 1949 (CMD. No. 7910) 263 (1950).

113. NHS (General Medical and Pharmazeutical Services) Regs. S. I. 1948, No. 506 First Schedule pt. II $\$ 1$; Remuneration of Doctors Under the National Healti SERVICE (British Information Services I.D. No. 906 rev.) 1, 2 (1950).

114. See speech of Bevan, 422 H. C. Deb. 55 (5th ser. 1946). The standard of remuneration for general practitioners is based on recommendations made by a committee of medical and lay members under the chairmanship of Sir Will Spens. The Spens Committee findings were accepted and published by the government. REPORT OF THE Inter-Departarental Committee on the Remuneratron of General Practimioners (CMd. No. 6810, 1945-46).

From a Central Pool capitation fees of 18 shillings per person are allocated for $95 \%$ of the population. This sum amounts to over $41,000,000$ pounds and from it 2,000,000 pounds is deducted for the Mileage Fund which supplements the earnings of doctors in rural districts. The balance is divided among Executive Councils who distribute their share of the Central Pool among doctors on their list. Select Comamttee Report on ADMINISTRATTON OF NHS, 1949 \23.

115. Id. at 14-17; 422 H. C. Deb. 55 (5th ser. 1946) ; and 428 H. C. Deb. 1122,1126 (5th ser. 1946). "We not only desire in this scheme to relieve patients of financial anxiety; but we desire to relieve the doctor of financial anxiety when he approaches his patients." Speech of Bevan, 447 H. C. DEв. 41 (5th ser. 1948). A doctor who receives the fixed annual payment of 300 pounds has his capitation fee reduced by one-seventh. During the first nine months of operation fixed payments were granted to over 2,000 doctors. Report of the Ministry of Health, 1949 (CMD. No. 7910) 264 (1950).

116. For a discussion of the operation of this dual system of payment see Practitroner's Review of NHSA 8, 30, 31, 43, 44; Britise Medrcal J. 709-12 (March 25, 1950). And see NHS (General Medical and Pharmaceutical Services) Amendment Regs. S.I. 1948, No. 1448 Reg. 2(8). ReMuneration of Doctors under the National Hralte Service (British Information Services I.D. No. 906 rev.) 1, 2 (1950). 
Supplementary payments are made for treating patients unable to visit the doctor with whom they are registered, for treating emergency cases, for training of assistants, for handling maternity cases, and for supplying drugs and appliances. In addition, mileage payments are made to augment earnings of doctors in rural districts, and inducement payments are provided for doctors willing to practice in unattractive areas. Finally, a doctor may continue to draw income from private practice. ${ }^{117}$

Salary: Specialists are paid by salary for full-time services. But most work only part-time and are paid on a half-day session basis. ${ }^{118}$ The Act prohibits issuance of any regulation which would require a specialist to work full time for the public service. ${ }^{119}$

Protecting the right of the specialist to practice privately has come into conflict with the right of the patient. For example, a patient may have to wait several months to undergo a routine operation in the service, though a specialist may be willing to perform the same operation immediately on a private basis. ${ }^{120}$ To prevent such abuse, ceilings on charges for specialists' work outside the service have been set. ${ }^{121}$ In addition to salaries, distinction awards made annually by a committee of eminent medical men entitle $24 \%$ of the specialists to sums ranging from $£ 500$ to $£ 2,500 .{ }^{122}$ Salaries for specialists have been set high and pay for medical staff-in-training has been raised in order to attract young doctors previously deterred by numerous risks and the likelihood of many lean years. As a result, recruitment of general practitioners seems seriously endangered. ${ }^{123}$

Fee for service: Dentists are paid on a fee for service basis which has caused some curtailment of professional freedom. To prevent waste of public funds on unnecessary treatment, estimates of certain complex and expensive dental work must be submitted to the Dental Estimates Board for prior approval. ${ }^{124}$ This system is cumbersome. It requires itemized billing and

117. Id. at 2-4; NHS (General Medical and Pharmaceutical Services) Regs. S.I., 1948, No. 506 First Schedule, pt. II; note 114 supra.

118. Eleven sessions constitute a full working week i.e. one session entitles a specialist to $1 / 11$ of a week's salary. RAPPLEYE, op. cit. supra note 24 , at $18-20$; Hill \& Wooncock. The National Health Service 36-42, 277, 278 (1949).

119. NHS (Amendment) A $\$ 12$. And see 465 H. C. DEB. $10 \$ 2$ (5th ser. 1949).

120. Id. at 1095.

121. NHSA $\S 5(2) ; 425$ H. C. DeB. 1780 (5th ser. 1946) ; RAPpleye, op. cit. supra note 24 , at 21 .

122. Id. at 19; Report of the Mrnistry of Health, 1949 (CMd. No. 7910) 250 (1950).

123. BRady, CRISIS in Britain 387 (1950); Rappleye, op. cit. supra note 24, at 20-21; British Medical J. 709-12 (March 25, 1950); speech of Dr. Hill, 490 H.C. DeB. 143 (5th ser. 1951); speech of Blenkinsop, Parliamentary Secretary to the Ministry of Health, 490 id. at 169.

124. Select Commitee Report an Administratron of NHS, 1949 \{f 33 ; NHS (General Dental Services) Regs. S.I., 1948, No. 505 Second Schedule; S.L., 1948, No. 1257 Second Schedule; NHSA $\$ 402$ (d). 
auditing and thus considerable paper work. ${ }^{125}$ Furthermore, there is some evidence that the Board's decisions have been based on economic rather than clinical grounds. For example, estimates for complete extractions, a non-recurring expense, have been approved without individual consideration, while estimates for more skillful conservative dentistry, which regulations seek to favor, are most carefully scrutinized. ${ }^{\mathbf{1 2 6}}$

By setting the scale of fees to encourage conservation rather than extraction, it became advantageous for dentists to give some treatment under the Scheme and to leave less remunerative treatment to private practice. ${ }^{127}$ Such misuse of the right to practice privately has not been widespread. The private work of National Health Service dentists represents less than 5\% of their total work. ${ }^{128}$ Parliament therefore rejected a motion to prohibit part-time practice in the Scheme. It preferred to rely on a regulation prohibiting discrimination among different parts of the full treatment required by a patient accepted for care under the National Health Service. ${ }^{129}$ Other abuses might be mitigated by controlling private fees, as is done with specialists. ${ }^{130}$

High rates and the release of a large demand have caused dentists to constantly work at greater speed and for longer hours than ordinarily. ${ }^{131}$ To control this tendency and to reduce costs, an emergency regulation reduced fees after earnings reached a certain ceiling. The rule failed, for while dentists stopped working for the Service at the ceiling point, they continued to treat private patients. A later regulation removed the ceiling and substituted an overall cut in rates. ${ }^{132}$ The results of this cannot yet be appraised. The government argued however, that these are physical rather than statutory difficulties which could be solved only by training an adequate number of dentists. ${ }^{133}$ Meanwhile fee for service payments result in more treatment than could be expected under a salaried service. ${ }^{\mathbf{1 3 4}}$

125. Seiect Conamitee Report on Administration of NHS, 1949 pp. 27-40. The Dental Board receives 180,000 estimates a week. $I d$. at 27. During the first 9 months of operation 109,000 of $3,800,000$ cases received by the Board were returned to the dentists for additional information. Id. at 29.

126. Id. at 35-6; Practitioner's Review of NHSA 58-9.

127. Select Commitiee Report on Adninistration of NHS, 1949 31, 35-6; Record Second Executive Council's Assoc. Meeting 74 (1949).

128. See note 34 supra.

129. 468 H.C. Deb. 603-18 (5th ser. 1949).

130. "Really, what was the matter at the beginning of the scheme was that we had exploitation of scarcity value by the dental profession as a whole." Speech of Bevan, id. at 616 ; and see note 121 supra.

131. Report of the Working Party on Chairside Tunes Taken in Carrying Out Treatment for General Dental Practitioners in England, Wales, and Scotland (H.M.S.O., No. 32-393) IT 28, 29, 47, 63(2), (3), (5), and (11) (1949).

132. Select Commitree Report on AnMinistration of NHS, $1949 \Uparrow 32 ; 475$

H.C. DEB. 911 et seq. (5th ser. 1950) ; and speech of Blenkinsop, id. at 928-35.

133. See, e.g., speech of Bevan, 465 H.C. DEB. 1176 (5th ser. 1949).

134. Practitioner's Review of NHSA 54. "No-one can claim that the fee for service is a good method of remuneration; although for historical reasons it has had to be re- 
None of the methods of payment negotiated necessarily endangers the freedom of the doctor to practice without interference. However, under a National Health Scheme this danger seems greatest not in a salary but in a fee for service system. ${ }^{135}$

\section{Some Limitations on the General Practitioner's Freedom}

Though a doctor remains free to enter the public service while continuing his private practice, he must not take fees from patients on his or his partner's list. ${ }^{130}$ His right to accept or reject anyone who applies for inclusion on his list is restricted in two ways. In the interest of good medical care he is limited as to the number of patients he may take on. ${ }^{137}$ On the other hand, since everyone is guaranteed medical service, a doctor may be asked to accept persons who, unable to obtain another practitioner, are assigned by his Executive Council. ${ }^{138}$

The general practitioner has been subjected to much paper work. The increased burden of prescriptions and records may be due to newly created demand for medical care. Most of the burden, however, is caused by more than 25 enactments, including social security benefits, which require certificates signed by a doctor. ${ }^{139}$ The problem of unnecessary paper work was

tained. The problem is how to remunerate on the basis of a uniform fee a profession with vastly differing standards of speed and workmanship .... [M] ore thought is required particularly in the dental profession to evolve a better system of remuneration." Address of Sir John A. Charles, chief medical officer of the Ministry of Health, in REcoRd THIRD Executive Councils' Assoc. Merting 93 (1950).

135. For a discussion of these methods of payment in relation to a proposal for an American health service, see Comment, Essentials of an Adequate Health Program, 59 YALE L.J. 292, 309-12 (1950).

136. NHS (General Medical and Pharmaceutical Services) REgs. S.I., 1948, No. 506 First Schedule pt. I $\$ 10$.

137. Id. pt. IV $\$ 13(2),(3),(4)$. A doctor practicing alone may have 4,000 patients; if he has a partner the senior is allowed to have 5,000 on his list and the junior 3,000 . For each permanent assistant a doctor is allowed another 2,400. A doctor with 4,000 on his list does not treat all these patients every year. He is probably consulted by fewer than half of those enrolled. HealTh Service Quiz (British Information Services I.D. No. 949 rev.) 2 (1950). For the view that the maximum should be reduced to 2,500 or 3,000 , with an increase in the capitation fee to insure better treatment, see PRACrITIONER's ReVIEW of NHSA 39. Patients transferred from doctors exceeding their maximum are free to select any other doctor. $437 \mathrm{H}$. C. Deв. (written answer) 75 (5th ser. 1950). And see A National Healti Service (Cand. No. 6502) 34 (1944).

138. NHSA $\$ 33(2)(c)$; NHS (General Medical and Pharmaceutical Services) Regs. S.I., 1948, No. 506 pt. IV § 13(b) ; and Select ComMrtTee Report on AdministraTION of NHS, $1949 \llbracket 16$. At the outset a few doctors were willing to take only healthy patients. $I d$. at 21 .

139. A doctor is required to issue to his patients free of charge "such certificates as may be prescribed, being reasonably required by them under or for the purpose of any enactment." NHSA $\$ 33$ (2) (d) as amended by NHS (Amendment) A, 1949 pt. II p. 30; NHS (General Medical and Pharmaceutical Services) Regs. S.I., 1948, No. 506 First Schedule $\$ \S 6(7)$, (10), (11), (12), and (13). See 425 H. C. DEB. 1915 (5th 
the subject of a recent investigation which advised that a doctor's certification functions be confined to medical information and that certificate forms be standardized. ${ }^{1 \pm 0}$ Though paperwork is now heavy, it need not be burdensome in a National Health Service.

\section{Investigation of Complaints and Disciplinary Procedure}

Although professional personnel are free to pursue their own methods, ${ }^{141}$ provisions ensure that doctors, dentists, opticians, and chemists comply with the terms in their contracts of service. ${ }^{142}$ In order to safeguard the interests of the public without jeopardizing the rights of the professional members, a complex administrative procedure for the investigation and adjudication of complaints has been devised. ${ }^{143}$ But no disciplinary body may determine whether a doctor is qualified to practice medicine; its only concern is with his actions as a member of the National Health Service. ${ }^{144}$

The procedural structure seems based on the principle that doctor be judged only by doctor when purely professional issues are involved, and by both doctor and layman when lay interests are at stake. The dividing line

ser. 1946) and 468 H.C. DEB, 595 (5th ser. 1949). For a list of Acts requiring certificates see RAPPLEYE, op. cit. supra note 24, at 6-7.

"In some ways the doctors' work is less complex. Some, for example with fewer private accounts, no longer need secretaries." 255 THE LANCET 824 (1948).

140. Report of the Interdepartalental Cominittee on Medical Certificates (H.M.S.O. 32-398) IIT 19, 24, 25 (1949). For the testimony of the British Medical Association see id. at IT 334-89. See also 157 THE Economist 1460 (1949).

141. See, e.g., statement of Dr. Dain, chairman of the Council of the British Medical Association, reprinted in Hearings before a Subcommittee of the Committee on Labor and Public Welfare on S. 1106, S. 1456, S. 1581, and S. 1679, 81st Cong., 1st Sess. 1065 (1949). "It is not my practice to interfere with the advice the doctor considers he should give his patient", answer of Bevan, Minister of Health, in reply to question concerning a doctor's refusal to provide information on contraceptives, in $473 \mathrm{H}$. C. DEB. 1348 (1950); Select Committee Report on Aditrnistration of NHS, 1949 p. 22; A National Health Service (Card. No. 6502) 26, 47 (1944).

142. NHSA $\$ 33(2), 38(2), 40(1), 41$. Terms of service in a doctor's contract with an Executive Council cover such matters as (a) persons for whose treatment the practitioner is responsible, (b) range of service, (c) such responsibilities of the practitioner as adequate office facilities, office hours, visits to confined patients, etc., (d) acceptance of private fees, (e) remuneration, and (f) withdrawal from the medical list. NHS (General Medical and Pharmaceutical Services) Regs. S. I., 1948, No. 506 First Schedule. For terms of service of chemists, see id. Fourth Schedule; of dentists, see NHS (General Dental Services) Regs. S.I., 1948, No. 505 First Schedule; and of opticians, see NHS (Supplementary Ophthalmic Services) Regs. S.I., 1948, No. 1273 Regs. 4, 5, 6 and First Schedule pt. III.

143. See, generally, 425 H. C. DEB. 1971 et seq. (5th ser. 1946) ; Hill \& Woodcock, The National Health Service 127-55 (1949).

144. See 425 H. C. DEB. 1976, 1987, 1991 (5th ser. 1946). Provisions for the registration of qualified doctors are found in the Medical Act, 1950, 14 GEo. 6, c. 29. A Medical Disciplinary Committee has jurisdiction over the doctor as a doctor, i.e., for unprofessional conduct. Id. \$\$14-21, 32. 
has been difficult to draw. As a result, an unduly intricate and cumbersome administrative procedure has evolved. ${ }^{145}$

Minor penalties: Investigations of such "professional" misconduct as excessive prescribing, keeping inadequate medical records, or taking unauthorized fees, are made by a Local Medical Committee composed exclusively of doctors. ${ }^{146}$ This Committee must furnish the accused with a written statement of the charges brought by the Minister. ${ }^{147}$ Following a hearing, the Committee determines, for example, whether there has been excessive prescribing. It does not decide what action should be taken. ${ }^{148}$ The practitioner is entitled to appeal to the Minister, who appoints a board of up to three members to make findings. One member must be a doctor, and none may be from the Ministry of Health. ${ }^{149}$ Likewise, if the Minister is dissatisfied with a Local Committee's determination, he may refer it to a similar board. ${ }^{150}$

After this procedure the Local Executive Council in turn recommends to the Minister any disciplinary action, for example, a fine for excessive prescribing. The doctor is then entitled to contest the proposed penalty by appeal to the Minister, who must appoint another board of hearing. Following this second appellate decision, the Minister may finally direct the Local Executive Council to take action. ${ }^{151}$

Any complaint by a patient concerning the conduct of a doctor is investigated by a Medical Service Committee, composed of medical and lay members. ${ }^{152}$ The Committee may examine allegations of breach of the terms of service such as a doctor's failure to exercise reasonable care, to treat a patient, or to order necessary drugs. ${ }^{153}$ Proceedings are informal, private, and non-adversary. The parties may have the assistance of another person who may not, however, address the Committee or examine witnesses. ${ }^{154} \mathrm{~A}$ report which contains conclusive findings of fact, inferences from the facts, and a recommendation for action is made to the Local Executive Council. ${ }^{155}$

145. See Robson, Justice and Administrative Law 143, 144 (3rd ed. 1951).

146. Note 87 supra; and NHS (Service Committees and Tribunal) REgs. S.I., 1948, No. 507 Regs. 12-16. These regulations apply to the dental and pharmaceutical services.

147. Id. Regs. $12(2), 13(2),(3)(a), 14(2),(3)(a), 16(2)$.

148. E.g., id. Reg. 12(3),(4). If the Committee decides excessive cost has been incurred it determines the amount of excess cost.

149. E.g., id. Reg. 12(5).

150. E.g., id. Reg. 12(6).

151. E.g., id. Reg. 11(1),(2),(3), 12(7).

152. See note 91 sllpra.

153. NHS (Service Committees and Tribunal) ReGs. S.I., 1948, No. 507 Reg. 4(1), (4). Similar regulations apply to complaints alleging failure to comply with terms of service in the dental, pharmaceutical and optical services. Id. Regs. 4(2),(3), 11(3) (b), and NHS (Supplementary Ophthalmic Services) Regs. S.I., 1948, No. 1273 Regs. 19-22.

154. NHS (Service Committees and Tribunal) Regs. S.I., 1948, No. 507 Reg. 5(1), (2),(3) and First Schedule.

155. Id. Reg. 5(4). 
The Local Executive Council may impose one of several penalties. Except for a decision to take no action, letters of warning are most common. ${ }^{15 B} \mathrm{~A}$ doctor's list of patients may be reduced if, after consultation with the Local Medical Committee, the Council finds him unable to treat adequately every-

156. Id. Reg. 6.

Reports of Service Committees (England and Wales) 5th July, 1948-31st March, 1951*

\begin{tabular}{|c|c|c|}
\hline \multirow{5}{*}{ MIEDICAL } & \multirow{2}{*}{\multicolumn{2}{|c|}{$\begin{array}{l}\text { Recommendations of } \\
\text { Executive Council } \\
\text { Number Received } \\
\text { from } 5.7-43 \\
\text { to } 31-3.51 \\
\ldots . . . \quad 3 \\
\text {. }\end{array}$}} \\
\hline & & \\
\hline & Other Action $\dagger$....... & 17 \\
\hline & Warning Letters ...... & 91 \\
\hline & 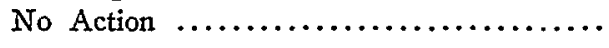 & 399 \\
\hline & Total $\ldots \ldots \ldots \ldots$ & 577 \\
\hline DENTAL & 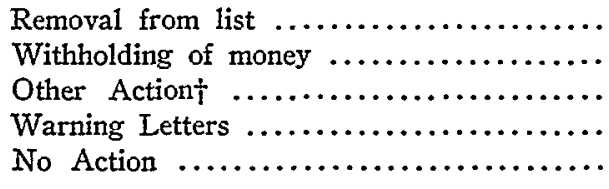 & $\begin{array}{r}19 \\
199 \\
470 \\
117 \\
879\end{array}$ \\
\hline & 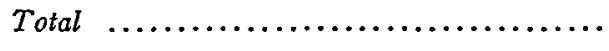 & 1684 \\
\hline PHARMACEUTICAI & 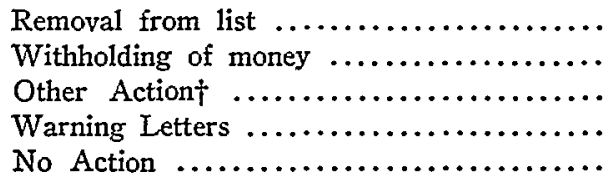 & $\begin{array}{r}2 \\
396 \\
1 \\
507 \\
311\end{array}$ \\
\hline & Total $\ldots \ldots \ldots \ldots \ldots \ldots \ldots \ldots \ldots \ldots \ldots$ & 1217 \\
\hline OPHTHALMIC & 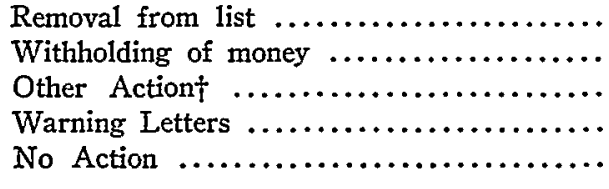 & $\begin{array}{r}8 \\
45 \\
19 \\
21 \\
48\end{array}$ \\
\hline & 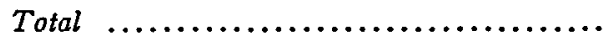 & 141 \\
\hline GRAND TOTAL & 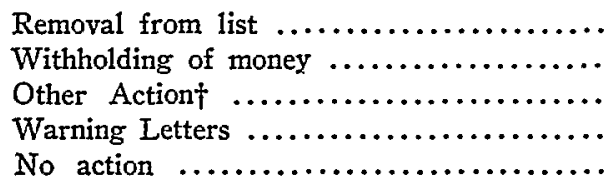 & $\begin{array}{r}32 \\
707 \\
507 \\
736 \\
1637\end{array}$ \\
\hline & Total & 3619 \\
\hline
\end{tabular}

*Source: Communication to the YaLE LAw Journar from R. Dempsey of the Ministry of Health, May 8, 1951.

f"Other Action" includes: a. Reimbursement by practitioner of patient's expenses; b. Fixing special list for doctor; c. Withholding from dentist cost of unsatisfactory work (where a larger withholding is proposed, the case comes under withholding of money); d. Requiring dentist to submit all estimates for prior approval. 
one on his list. ${ }^{157} \mathrm{He}$ may be ordered to reimburse a patient for unnecessary expenses due to professional misconduct. ${ }^{158}$ Finally, if the Council believes his participation in the Scheme is prejudicial to Service efficiency, a charge for his removal is filed with the National Health Service Tribunal. ${ }^{150}$

In all but the last action, a doctor has direct appeal to the Minister. ${ }^{160}$ The Minister may appoint a board of three which must in most cases include a medical member. ${ }^{161}$ Parties may be represented by counsel and on written notice may introduce new evidence. ${ }^{162}$ After receiving the report of the hearing the Minister renders a final decision. ${ }^{163}$ Very few appeals have been brought from Local Executive Council decisions, and in those few the Councils have generally been upheld. ${ }^{164}$

Little justification appears for dividing jurisdiction of the Service Committees, with both lay and medical members, from that of the Local Medical Committees. Lay members of the Service Committees are as concerned as doctors with misconduct such as excessive prescribing or failure to keep proper records. These matters are often of wider public import and less technical than many which may go before Service Committees. ${ }^{165}$

Dismissal from the Service: Dismissal of a doctor from the Service is a severe penalty. Since more than $95 \%$ of the population have joined, private practice seems unlikely to be a satisfactory method of earning a living. ${ }^{166}$ At the same time, power of dismissal must be available to ensure that practitioners carry out their terms of service and observe professional standards of care. Since a Minister is obligated to Parliament to provide satisfactory services, he might have been empowered to discharge anyone in whom he lacked confidence. ${ }^{107}$ But such a policy would reduce the doctor to a servant of the state.

157. NHS (Service Committees and Tribunal) Regs. S.I. 1948, No. 507 Reg. 6(a).

158. Id. Reg. 6(b).

159. Id. Reg. 6(d).

160. Id. Reg. 7. The Minister may dismiss appeals which have "no reasonable grounds" or are "vexatious or frivolous". But appeal from a Council decision involving penalties under Reg. $6(\mathrm{a}),(\mathrm{b}),(\mathrm{c})$ or (e) may not be dismissed without providing the appellant with the opportunity of an oral hearing. Id. Reg. 9(1).

161. Id. Reg. $9(5)$.

162. Id. Reg. $9(6),(7)$.

163. Id. Reg. $9(5)$.

164. Between 5 July 1948 and 31 March 1951, 210 Executive Council decisions out of 3619 in disciplinary cases involving the Medical, Dental, Pharmaceutical and Ophthalmic professions were appealed. Of the 210 appeals, 111 were dismissed, 27 were granted, and in 72 no decision was rendered. Communication to the YaLE LAW Journal from $R$. Dempsey of the Ministry of Health, May 8, 1951; and note 156 supra.

165. See Robson, op. cit supra note 146, at 144. One of the advantages of administrative committees is the technical knowledge which they make avialable for the discharge of judicial functions in special fields. Id. at 562 .

166. See speech of Reed, 425 H. C. DEB. 1971 (5th ser. 1946) ; speech of Bevan, id. at 1979; and note 34 sipra.

167. 425 H. C. DEB. 1971 (5th ser. 1946); note 62 supra. 
Parliament decided therefore that no doctor, dentist, optician, or druggist should be deprived of his place in the Scheme without a fair hearing. ${ }^{108}$

A National Health Service Tribunal inquires into charges that continuance in the service of any member of the professions would impair Service efficiency. ${ }^{169}$ The Tribunal consists of a barrister or solicitor who serves as chairman, a Local Executive Council representative, and a professional member. The chairman is appointed by the Lord Chancellor, the other members by the Minister of Health. The professional member represents a branch of practice similar to that of the practitioner whose conduct is under consideration. ${ }^{170}$

The Tribunal must hear any case brought by an Executive Council. ${ }^{171}$ However, the Tribunal may suspend its proceedings in a case where the alleged facts are the subject of investigation of a body outside the National Health Service. For example, as only registered doctors are entitled to practice for the Service, the Tribunal would await the decision of the Medical Disciplinary Committee which has the power to remove doctors from the Register. ${ }^{172}$ The Executive Council's complaint must not be accompanied by details of its investigation or any evidence which might cause the Tribunal to prejudge the case. ${ }^{173}$ The accused is given written notice of all allegations. He may be represented by counsel, call witnesses and require that hearings be held in public. ${ }^{174}$ The object of private hearings is to protect a doctor's reputation from damaging allegations that may prove unfounded..$^{175}$

The Tribunal is empowered to impose only the penalty of exclusion from the service or no penalty at all. ${ }^{176}$ This limitation may lead to unsatisfactory results. For example, one case involved a doctor who delayed several hours before attending a baby. Under the influence of liquor, he failed to appreciate

168. "A doctor is appointed. Before a doctor can be removed [from the service]. something has to be proved against him. It is not enough for the Minister to dislike the colour of his hair. . . It is not enough for the Minister to dislike the sound of his voice or his politics." Speech of Bevan, 425 H. C. Deb. 1974 (5th ser. 1946). Also see id. at 1974-6; and 447 H. C. DeB. 43-6 (5th ser. 1948).

169. NHSA $\S 42$.

170. NHSA Seventh Schedule as amended by NHS (Amendment) A $\$ 21(1)$. Thus the composition of a Tribunal will depend on whether the case under investigation concerns, for example, a country doctor in general practice, an urban doctor in general practice, or a specialist in a great city. See 465 H. C. DEв. 1072 (5th ser. 1949).

171. NHSA $\$ 42(3)$; and NHS (Service Committees and Tribunal) Regs. S.I., 1948, No. 507 Reg. 26.

172. Id. Reg. 38 and note 144 supra.

173. Id. Reg. 25; see also Ministry of Health Circular E.C.L., 1949, No. 194 discussed in 99 THE L.J. 319 (1949).

174. NHSA $\$ 42(7)(a)$; and NHS (Service Committees and Tribunal) REGs. S.I., 1948, No. 508 Regs. $27-30$.

175. See Robson, op. cit. supra note 146, at 132 . This intent may be defeated, however, by another section of the Act which provides for the publication of decisions by the Tribunal and the Minister. Thus, in the event of acquittal, the name of the respondent and the allegations may become public. NHSA $\$ 42(7)(\mathrm{c})$; see, e.g., note 177 infra.

176. NHSA § 42(1),(3). 
the fatal nature of the baby's illness and remained only a short time. The Tribunal found that no treatment would have saved the child and that the doctor's negligence did not contribute to the death. It held that this single incident did not justify expulsion from the service and imposed no penalty of any kind. ${ }^{\mathbf{1 7 7}}$

While no one can challenge a Tribunal decision in his favor, the practitioner may appeal an adverse decision to the Minister of Health. ${ }^{178}$ Another hearing, with all the safeguards of a Tribunal proceeding, is held before a person appointed by the Minister. After receiving the report of this hearing, the Minister cannot make a final decision in any case involving a doctor or a dentist. He must first refer the report to an Advisory Committee of six doctors or dentists, three of whom are nominated by the professional organization concerned. Only then can a final decision be rendered. ${ }^{179}$

177. Case of John William Paterson Collier, NHS Tribunal Report, 9/49/73. For a discussion of this problem and the suggestion that more use be made of the National Health Service Tribunal in the most serious cases see ROBSON, op. cit. supra note 146, at 144-5.

178. NHS (Service Committees and Tribunal) Regs. S. I., 1948, No. 507, Reg. 41.

The British Medical Association claimed the right of appeal on the merits to the courts (rather than to the Minister) from a Tribunal. The Minister of Health, with responsibility for a health service, asked who then would be responsible for a death caused by negligence of a doctor first dismissed by the Tribunal and then reinstated by the High Court. He contended that the Minister of Health would have to reply: "I did not appoint the doctor; it was the High Court judge." He successfully argued that this would place the judiciary in a position that the British Constitution never intended. $425 \mathrm{H}$. C. DEB. 1981, 1982 (5th ser. 1946); 447 H. C. DEB. 43-6 (5th ser. 1948); and Note, The British Doctors and the New Health Service, 22 The Social Service Rev. 252, 253 (1948). And see note 181 infra.

179. NHS (Service Committees and Tribunal) REgs. S.I., 1948, No. 507 Regs. 11(4), $(5),(6), 42$. The following table indicates the disposition and number of cases in each profession in which the Executive Council has recommended dismissal from the Service during the first 2 years and 9 months of operation:

Cases referred by Executive Councils to Tribunal 5th July, 1948-31st March, 1951.*

\begin{tabular}{|c|c|c|c|c|c|c|c|c|c|}
\hline & \multicolumn{5}{|c|}{ TRIBUNAL'S DECISION } & \multicolumn{4}{|c|}{$\begin{array}{c}\text { APPEALS TO MINISTER } \\
\text { AGAINST TRIBUNAL'S } \\
\text { DECISION }\end{array}$} \\
\hline Profession & No. & $\begin{array}{l}\text { Removal } \\
\text { from } \\
\text { Execu- } \\
\text { tive } \\
\text { Council's } \\
\text { List }\end{array}$ & $\begin{array}{l}\text { Execu- } \\
\text { tive } \\
\text { Council's } \\
\text { Appli- } \\
\text { cation } \\
\text { Dis- } \\
\text { missed }\end{array}$ & $\begin{array}{l}\text { Cases } \\
\text { Not } \\
\text { Fleard }\end{array}$ & $\begin{array}{l}\text { Decision } \\
\text { Not Yet } \\
\text { Given }\end{array}$ & No. & $\begin{array}{l}\text { Appeals } \\
\text { Upheld }\end{array}$ & $\begin{array}{l}\text { Appeals } \\
\text { Dis- } \\
\text { missed }\end{array}$ & $\begin{array}{l}\text { Decision } \\
\text { Not Yet } \\
\text { Given }\end{array}$ \\
\hline Medical & 3 & 1 & 1 & $1 \uparrow$ & - & 1 & - & - & 1 \\
\hline Dental & 19 & 7 & 4 & $2+1$ & 6 & 2 & 一 & 1 & 1 \\
\hline Pharmaceutical & 2 & 1 & 一 & - & 1 & 1 & 1 & - & - \\
\hline Opthalmic & 8 & 3 & 3 & $1 \dagger$ & 1 & 1 & - & 1 & 一 \\
\hline Total & 32 & 12 & 8 & 4 & 8 & 5 & 1 & 2 & 2 \\
\hline
\end{tabular}

* Source: Communication to the YALE LAw JouRnal. from R. Dempsey of the Ministry of Health May 8, 1951.

$\dagger$ Respondent permitted to resign before case heard.

itExecutive Council's application withdrawn; respondent agreed not to practice under NHS. 
Publication of the name of an offender, one of the most powerful disciplinary sanctions, is prohibited in all decisions except those concerning removal from the Service. Three reasons have been advanced for this policy. Executive Councils have no statutory immunity from an action for damages. More important is the desire to protect individuals from the uncontrollable penalty of injury to reputation. Finally, unlike the National Tribunal, the Local Committees lack some of the procedural safeguards available in a court of law. ${ }^{180}$

Excluding possible resort to the courts for challenging the procedure of the Committees, ${ }^{\text {si } 1}$ there are five possible stages of inquiry through which cases may have to pass before a final decision is reached. Each has elaborate safeguards as to procedure and personnel. A complaint against a doctor may begin at Service Committee, go to a Local Executive Council and then to a Tribunal. From there, the respondent may appeal to the Minister, who must arrange another hearing. Finally, the matter must go before a medical advisory committee. The Minister may then decide.

The number of stages seems excessive and must result in waste of time, energy, and money. Without jeopardizing rights of the accused, a hearing with the right of appeal should generally suffice. It might be desirable to have a third stage in cases involving exclusion from the service. ${ }^{182}$ Cumbersome as the present procedure is, it does indicate that adequate techniques can be devised to protect professional personnel in a National Health Service from becoming servants of the state subject to the whim of Ministers with ever changing political complexion.

\section{ConClúsion}

Britain sought a new method of providing health care. With the National Health Service Act, a great experiment in welfare legislation has been set in motion. Parliament has not drafted a rigid plan, for it has recognized the need for constant review and revision. Numerous administrative techniques have been devised to allow interested parties to participate in the Service's development. Though a national program, a high degree of decentralization coupled with widespread participation prevents the impress of uniformity or regimentation from above.

The Act is a product of the democratic process. Its provisions were drafted after consultation with all interested parties and enacted after long debate. Little if any reason for either patients or professions to remain outside the

180. 468 H. C. DEB. 645-7 (5th ser. 1949). An amendment to permit publication of the particulars of a disciplinary action including the name of the respondent was defeated. Id. at 647 .

181. A doctor may appeal to the court on any one of three grounds: (a) that procedure for his trial had not been properly carried out; (b) that one of the tribunals or the Minister had exceeded their respective powers; (c) and that principles of natural justice had been violated. $425 \mathrm{H}$. C. DEB. 1979-81 (5th ser. 1946) and 447 H. C. DEB. 46 (5th ser. 1948).

182. See Robson, op. cit supra note 146, at 145. 
Service is left. But an element of competition has been preserved. Not only does the patient retain his freedom to choose and change his doctor, but the removal of financial obstacles to care has enlarged this choice. The professions are free from compulsion to join the Service-they may maintain both a public and private practice and are free from clinical interference. All have adequate representation at all levels of the administration. If anything, safeguards in administrative procedure err on the side of the elaborate.

It is too early to determine whether the National Health Service Act will achieve its objectives. In any event, their achievement will not be at the expense of individual rights. 